\section{Energy in buildings-Policy, materials and solutions}

Matthias M. Koebel, Jannis Wernery and Wim J. Malfait, Building Energy Materials and Components Laboratory, Swiss Federal Laboratories for Materials Science and Technology, Dübendorf 8600, Switzerland

Address all correspondence to Matthias M. Koebel at matthias.koebel@ empa.ch

(Received 12 December 2016; accepted 24 August 2017)

\title{
ABSTRACT
}

This manuscript provides a bird's eye view on energy in buildings. We discuss how energy policy leads to building standards that affect innovation in the building sector. We review current and future materials and solutions for the building envelope (insulation and glazing), renewable energy generation and energy storage, and demonstrate how the integration of buildings into district networks mitigates problems arising from a building's, and its users', dynamic behavior.

Buildings account for $\sim 40 \%$ of global energy demands, and the increased adoption of innovative solutions for buildings represents an enormous potential to reduce energy demands and greenhouse gas emissions. Here, we critically review the current and future materials and solutions for the construction sector. We describe how policy affects innovative businesses and the adoption of new products and solutions. We investigate how the building envelope and user behavior determine building energy demands. Compared to conventional solutions, superinsulation materials (vacuum insulation panels, silica aerogel) can achieve the same thermal performance with drastically thinner insulation. With low-emissivity coatings and appropriate filler gasses, double and triple glazing reduces thermal losses by an order of magnitude. Vacuum and aerogel glazing reduce these even further. Switchable glazing solutions maximize solar gains during wintertime and minimize illumination demands whilst avoiding overheating in summer. Upon integration of renewable energy systems, buildings become both producers and consumers of energy. Combined with the dynamic user behavior, temporal variations in energy production require thermal and electrical storage and the integration of buildings into smart grids and energy district networks. The combination of these measures can reduce the energy consumption of the building's stock by a factor of three.

Keywords: society; energy storage; insulator; sustainability

\section{DISCUSSION POINTS}

- Can policy convince stakeholders, building owners, and users to improve building energy efficiency?

- How do current building materials and technologies complement each other toward building energy efficiency?

- Which new materials and solutions are likely to have a strong impact in the building sector?

\section{Background and global context}

Society is facing drastic environmental and geopolitical impacts from climate change. There is evidence for significant acceleration of global warming, and experts warn of a point of no return calling for $\mathrm{CO}_{2}$ emissions to be stabilized. To turn the world's energy infrastructure and systems around in time before the most detrimental climate change effects can no longer be undone, ${ }^{1}$ passionate policy makers must meet innovative engineers and entrepreneurs because the implementation of innovative solutions relies heavily on both the economic and the political landscape.

First off, climate change must be perceived as a problem to create the necessary political pressure needed for policy changes. But who makes the public opinion of global warming? At the end of the 1980s, the greenhouse effect made frontline news following a testimony at a U.S. senate climate hearing. ${ }^{2}$ Despite the broad consensus of international experts on climate change, ${ }^{3,4}$ there was a strong, well-organized opposition (thinktanks, scientists with contrary positions) which began to question the mere existence of climate change, effectively stopping all efforts of the US government to impose $\mathrm{CO}_{2}$ emission regulations for a decade. ${ }^{5}$ Many of these activities were directly supported by the fossil fuel industry, which has a strong interest in playing down the effects of climate change. With the current 
political climate in the US, the same debate has again become a topic of great actuality and consequence, and scientist and experts worldwide have an obligation to take an active counter position in this postfactual age. Given today's very visible consequences of climate change, e.g., weather extremes ${ }^{6}$ and arctic record temperatures in 2016, most people have by now accepted that climate change is real and that it poses a significant risk to the continuation of life as we know it, but different groups of people worry in different ways about the possible consequences (nature and landscape, devastation, resource availability, diseases). For example, most Americans still think the consequences will primarily concern people from other continents or wildlife in general. ${ }^{7}$ Another study on the public perception in Europe shows that Northern Europeans are less concerned than Southern Europeans, commensurate with an increase in the expected comfort or discomfort (desired warmer weather versus too hot climate) resulting from global warming. When zooming in to a more local resolution, issues linked to effects on daily life seem to dominate, namely land erosion, flooding, and inability to qualify for insurance coverage etc. ${ }^{8}$

Second, we must turn our attention toward mitigation, and more specifically toward the role of policy and regulation changes. ${ }^{9}$ Generally, policy influences the real world in two ways, namely, (i) by providing a long-term roadmap and strategy that sets the overall goals of a society and (ii) to implement norms and standards needed to put the said strategy into action. In reality, political and industrial stakeholders are often closely related through political processes and mutual interests. Such concentration of power and mutual influencing can lead to serious adverse effects, e.g., "non-believers" and political stalemate situations leading to delayed action. The United States plays a central role in the discussion about climate change mitigation because of (i) its strong economic position and (ii) the role model character for second and third world countries in their quest for economic growth and success. This second point has a considerable influence on the energy policy of developing countries. In that sense, unfortunately, the strong economic focus of the US does not always send out the right signals to second and third world countries. Europe has been taking the climate change issue more seriously, most likely due to a stronger ecologist and left-wing influence in the political and public opinion and less direct influence of the petroleum industry in the government's decision making processes. The effect is seen by example of (i) the relatively early policy measures taken by the EU government (Table 1), (ii) the wide adaptation of climate targets by its membership countries, ${ }^{10,11}$ and (iii) the promising results in the form of $\mathrm{CO}_{2}$ savings, a substantial increase in renewable energy production, etc. (Table 2).

The climate change programs in Table 1 target to limit global warming to acceptable levels. The opinion of leading experts is that the anthropogenic emissions-based temperature increase has to be kept below $2{ }^{\circ} \mathrm{C}$ if a self-accelerating "runoff" scenario is to be avoided. ${ }^{12}$ This means limiting cumulative global $\mathrm{CO}_{2}$ emissions in the 2000-2050 period to 1000 Gtons or 1440 Gtons to yield a 50 and $25 \%$ probability, respectively, to stay within the $2{ }^{\circ} \mathrm{C}$ limit.
Since the advent of the Kyoto Protocol, most industrialized countries have attempted to reduce their $\mathrm{CO}_{2}$ emissions and oil consumption and to increase the fraction of electricity harvested from renewable sources. Again, we see the role model example of European countries like Sweden, Germany, and Spain (Table 2). On average, $2015 \mathrm{CO}_{2}$ emissions from these countries are roughly $15 \%$ lower than in 1995 . Because of the late participation and ineffectual commitment of the American continent, both North and South America are still significantly lagging behind on their Kyoto protocol targets. Total energy consumption has gone up by roughly $20-30 \%$ in North America and by a factor of two in Brazil. The increased energy consumption of Brazil tracks the strong economic growth over the last decade. $\mathrm{CO}_{2}$ emissions in North America are nearing stabilization, although some of this "success" must be attributed to the subprime economic crisis and its ensuing recession. The effect of the 2008 economic crisis on emissions also affects the emissions of the EU and Japan. Asia, as the world's commodities production factory, is experiencing a massive energy infrastructure ramp-up with rising energy consumption and greenhouse gas emissions, with the exception of Japan. Nevertheless, it must be noted that China takes its pollution problems very seriously and is making massive investments in electrical energy, vehicles, and transportation as well as production from renewable sources. ${ }^{14}$ In Russia, energy consumption is still increasing, but $\mathrm{CO}_{2}$ output is stabilizing. In the Middle East, fossil fuel-based electrification of infrastructures has led to an almost doubling of emissions since 1995.

\section{Policy as a link between political leaders and innovative businesses}

To better understand the different adoption rates of climate action programs such as the Kyoto protocol in different parts of the World, one must realize the balance of power between shortterm economic profit taking and long-term socioeconomic interest. From an economic point of view, a rebuild of the energy sector requires tremendous investments and risks taken along the entire value chain, by investors, distributors, and, importantly, early adopter consumers. This is particularly important for the building and construction sector, which is inherently conservative because of the long service life and large up-front investments. Policy can help drive the transition forward, but often also has unintended consequences. In Germany, the federal parliament has set the tone for over two decades with a renewable energy policy, often against reluctant governments and the vehement opposition from the nuclear and coal industry. ${ }^{15}$ The sustained support for renewable energy, including massive subsidies for wind and solar electricity in the form of feed-in tariff incentives, has increased the share of renewables in Germany's electricity mix by a factor of more than five between 1995 and 2015, leading to a substantial reduction in $\mathrm{CO}_{2}$ emissions (Table 2). In addition, the emergence of a mass market has drastically reduced the cost of PV. The record-breaking adoption of wind and PV technology in Germany contrasts with the situation in Japan, where the concentration 
Table 1. Climate change programs at global, regional and national levels.

\begin{tabular}{|c|c|c|}
\hline \multicolumn{3}{|l|}{ Global } \\
\hline \multirow[t]{3}{*}{ UNFCCC } & UN Framework Convention on Climate Change (1992) & Set forth protocols to create binding emission limits \\
\hline & Kyoto Protocol (1997) & $\begin{array}{l}\text { Legal groundwork to limit greenhouse gas emissions based on } \\
\text { nations capabilities }\end{array}$ \\
\hline & Paris Agreement (2017) & $\begin{array}{l}\text { Cap temperature rise \& peak emissions, team up research and } \\
\text { communication }\end{array}$ \\
\hline IPCC & Intergovernmental Panel on Climate Change (1998) & $\begin{array}{l}\text { Scientific panel to analyze and communicate climate change data } \\
\text { to policy makers }\end{array}$ \\
\hline ICAP & International Carbon Action Partnership (2007) & $\begin{array}{l}\text { Platform for governments and public bodies to facilitate } \\
\text { emissions credit trading }\end{array}$ \\
\hline \multicolumn{3}{|l|}{ Europe } \\
\hline ECCP & European Climate Change Programme (2000) & Identify, develop and implement framework to reach Kyoto protocol \\
\hline EU-ETS & European Union Emissions Trading System (2005) & Regulation of emissions through cap and trade $\mathrm{CO}_{2}$ credit system \\
\hline UK CCP & United Kingdom Climate Change Programme (2000) & Regulation of $\mathrm{CO}_{2}$ emissions going beyond Kyoto protocol targets \\
\hline \multicolumn{3}{|c|}{ United States of America } \\
\hline PCAP & Presidential Climate Action Plan (2013) & $\begin{array}{l}\text { Reduce emissions, climate change readiness, influence Global } \\
\text { policy }\end{array}$ \\
\hline \multicolumn{3}{|l|}{ Australia } \\
\hline CEA & Clean Energy Act (2011) & Reduction and regulation of $\mathrm{CO}_{2}$ emissions \\
\hline
\end{tabular}

on nuclear energy led to a decline of the Japanese PV market. ${ }^{16}$ On the downside, Germany's top-down focus on short-term consumer cost rather than total cost and market formation, ${ }^{17}$ left the market too dependent on subsidies, leading to a solar industry bubble. In addition to top-down policy measures, bottom-up innovation by businesses that couple risk with technological feasibility, can transform the energy market. For example, the success of Tesla Motors, driven by technological improvements on key bottle necks (range and charging times) and an innovative but risky direct-to-consumer business model, has changed the perception of the practicality and viability of electric vehicles not only from the general public but also from traditional car manufacturers.

\section{Global building standards and policy}

Buildings account for roughly $40 \%$ of the global energy demand, ${ }^{18}$ with changing energy demands due to climate change. ${ }^{19}$ The other two main energy intensive sectors are transportation $(\sim 25 \%)$ and industry $(\sim 25 \%)$. The transportation sector, particularly the automotive business, has been continuously increasing efficiency of drivetrains over the past two decades so that additional new savings come at a comparably higher price. Industry and services also offer only limited potential for efficiency gains without compromising competitiveness of first world countries with stricter environmental laws. The potential for energy demand reduction in buildings is a popular research and discussion topic nowadays. Despite a general tightening of building energy codes around the world,${ }^{20}$ the degree of implementation of various state-of-the-art technologies and solutions varies significantly from continent to continent and from country to country. When trying to assess the overall saving potential in buildings, the discussion must not always be led by a comparison of similar building types (residential, commercial, old, energy retrofitted, new) but also must be based on location and climate. Generally, buildings in northern climates have a higher overall energy demand and $\mathrm{CO}_{2}$ output because of the dominant heating demand which is most commonly powered by fossil fuel combustion. In warmer climates, the higher cooling loads are most often covered by chillers operating with electrical energy. 
Table 2. Primary energy consumption for the years 1995/2005/2015 based on the Enerdata Statistical Yearbook. ${ }^{13}$

\begin{tabular}{|c|c|c|c|c|c|c|c|}
\hline & $\begin{array}{c}\text { Total } \\
\text { [Mt oil eq.] }\end{array}$ & Oil [Mt] & $\begin{array}{l}\text { Gas } \\
{\left[10^{9} \mathrm{~m}^{3}\right]}\end{array}$ & Coal [Mt] & $\begin{array}{l}\text { Electricity } \\
\text { [TW h] }\end{array}$ & $\begin{array}{c}\text { Renewable } \\
\text { electricity [\%] }\end{array}$ & $\begin{array}{c}\mathrm{CO}_{2} \text { emissions } \\
{[\mathrm{Mt}]}\end{array}$ \\
\hline \multicolumn{8}{|l|}{ Europe } \\
\hline Sweden & $32 / 35 / 34$ & $16 / 14 / 10$ & $1 / 1 / 1$ & $5 / 5 / 3$ & $132 / 135 / 125$ & $47.6 / 51.9 / 64.3$ & $46 / 48 / 35$ \\
\hline Germany & $145 / 137 / 121$ & $128 / 112 / 97$ & $83 / 91 / 80$ & $274 / 244 / 232$ & $473 / 539 / 521$ & $6.6 / 11.7 / 32.2$ & $853 / 784 / 713$ \\
\hline Spain & $32 / 31 / 31$ & $52 / 68 / 48$ & $9 / 34 / 28$ & $43 / 44 / 28$ & $146 / 248 / 238$ & $15.7 / 16.1 / 35.5$ & $234 / 339 / 251$ \\
\hline \multicolumn{8}{|l|}{ America } \\
\hline Canada & $349 / 402 / 456$ & $79 / 101 / 100$ & 81/99/111 & $53 / 60 / 42$ & 467/533/493 & $61.0 / 59.6 / 62.7$ & $457 / 557 / 543$ \\
\hline US & $1655 / 1632 / 2012$ & 753/887/751 & $610 / 623 / 783$ & $872 / 1018 / 730$ & $3136 / 3811 / 3848$ & 11.7/9.4/13.8 & $5087 / 5753 / 5160$ \\
\hline Brazil & $112 / 195 / 280$ & $70 / 87 / 118$ & $5 / 20 / 41$ & $19 / 21 / 31$ & $262 / 371 / 514$ & $94.2 / 87.1 / 73.5$ & $235 / 314 / 455$ \\
\hline \multicolumn{8}{|l|}{ Asia } \\
\hline China & $1065 / 1764 / 2640$ & $152 / 297 / 505$ & $18 / 47 / 188$ & $1349 / 2646 / 3732$ & $848 / 2126 / 4921$ & 19.2/16.2/24.7 & $2984 / 6126 / 8948$ \\
\hline Japan & $98 / 100 / 98$ & 237/222/171 & $70 / 89 / 129$ & 130/180/190 & $871 / 993 / 921$ & $11.1 / 10.5 / 17.9$ & $1094 / 1168 / 1132$ \\
\hline $\begin{array}{l}\text { South- } \\
\text { Korea }\end{array}$ & $22 / 46 / 62$ & $88 / 88 / 96$ & $9 / 30 / 44$ & $44 / 83 / 130$ & $163 / 358 / 505$ & $3.1 / 1.4 / 2.1$ & $334 / 448 / 577$ \\
\hline \multicolumn{8}{|l|}{ ROW } \\
\hline Russia & $970 / 1203 / 1341$ & $133 / 117 / 143$ & $393 / 425 / 456$ & $263 / 213 / 207$ & $697 / 760 / 870$ & $20.7 / 18.6 / 16.3$ & $1611 / 1527 / 1620$ \\
\hline $\begin{array}{r}\text { Middle } \\
\text { East }\end{array}$ & $1138 / 1518 / 1879$ & $163 / 241 / 312$ & $132 / 256 / 473$ & $9 / 16 / 19$ & $297 / 528 / 935$ & 3.2/4.3/2.2 & $857 / 1274 / 1948$ \\
\hline Australia & $187 / 265 / 355$ & $33 / 40 / 45$ & $20 / 27 / 36$ & $102 / 138 / 118$ & $151 / 199 / 220$ & $9.8 / 8.9 / 15.2$ & 280/376/377 \\
\hline
\end{tabular}

In an attempt to better understand the existing building stock in different parts of the world, we summarize the currently implemented state-of-the-art technical solutions and compare them to the respective energy savings potential. Table 3 , shows a semiquantitative market analysis and suggested energy saving measures, based on various national policy studies. ${ }^{21-32}$ Efficient building envelopes with double or triple glazing, insulated walls, and a high degree of air tightness are standard in Europe, less so on the American continent, and adopted to an even smaller extent in Asia and in the rest of the world. Particularly airtight building envelopes are standard for new construction in Europe but not really for the rest of the world. According to Haines et al., ${ }^{9}$ potential energy and $\mathrm{CO}_{2}$ savings in the built environment on the order of $30 \%$ can be achieved by 2020 in a cost-effective manner with relatively minor intervention.
The deep-retrofitting potential on a single building scale can be by far higher $(65-80 \%)$ but with a high initial investment. Because many older buildings are built with older technology, e.g., poor windows and insulation standards, oil or coal heating systems, roughly $80 \%$ of buildings nowadays offer a sizable retrofitting potential.

\section{Building envelope}

The building envelope constitutes the separation between the interior and exterior of a building, i.e., between the conditioned and the unconditioned environment and has three main functions: (i) structure, (ii) control, and (iii) aesthetics. In many building styles, the envelope is a load-bearing part of the building and has to be designed accordingly. The building envelope 
Table 3. Currently implemented technologies and measures with the largest energy savings potential, modified from Ref. 33.

\begin{tabular}{|c|c|c|c|c|c|c|c|}
\hline & \multicolumn{5}{|c|}{ Currently implemented state-of-the-art technologies } & \multicolumn{2}{|c|}{$\begin{array}{l}\text { Energy savings potential (ESP) } \\
\text { and most effective action }\end{array}$} \\
\hline & $\begin{array}{c}\text { Low-e DG } \\
\boldsymbol{U}_{\mathrm{g}} \sim 1.0 \\
W /\left(\mathrm{m}^{2} \mathrm{~K}\right)\end{array}$ & $\begin{array}{c}\text { LoW-e TG } \\
<0.8 \mathrm{~W} /\left(\mathrm{m}^{2} \mathrm{~K}\right)\end{array}$ & $\begin{array}{l}\text { Air-tightness } \\
<5 \mathrm{~m}^{3} /\left(\mathrm{m}^{2} \mathrm{~h}\right)\end{array}$ & $\begin{array}{l}\text { Insulated } \\
\text { envelope }\end{array}$ & $\begin{array}{l}\text { Exterior } \\
\text { insulation }\end{array}$ & ESP $[\%]$ & $\begin{array}{l}\text { Actions with largest } \\
\text { potential }\end{array}$ \\
\hline Europe & & & & & & 21 & \\
\hline Greece & $* * *$ & ** & $* * *$ & $* * *$ & $* * *$ & 54 & $\begin{array}{c}\text { Envelope insulation, } \\
\text { lighting, water \& space } \\
\text { heating }\end{array}$ \\
\hline Germany & $* * *$ & ** & $* * *$ & $* * *$ & $* * *$ & $26 / 37$ & $\begin{array}{c}\text { Envelope insulation, } \\
\text { fuel switching, heating } \\
\text { systems }\end{array}$ \\
\hline UK & $* * *$ & ** & $* * *$ & $* * *$ & $* * *$ & 24 & $\begin{array}{l}\text { Efficient gas boilers, } \\
\text { envelope insulation }\end{array}$ \\
\hline
\end{tabular}

America

\begin{tabular}{l|c|c|c|c|c|c|c}
\hline Canada & $* * *$ & $*$ & $* *$ & $* * *$ & $* * *$ & 24 & $\begin{array}{c}\text { Fuel switching, landfill gas, } \\
\text { furnaces, envelope }\end{array}$ \\
\hline USA & $* * *$ & $*$ & $* *$ & $* * *$ & $* * *$ & 37 & $\begin{array}{c}\text { Lighting, space cooling, } \\
\text { space heating }\end{array}$ \\
\hline Brazil & $*$ & $*$ & $*$ & $* *$ & $*$ & 41 & No recommendations \\
\hline
\end{tabular}

Asia

\begin{tabular}{l|c|c|c|c|c|c|c}
\hline China & $*$ & $*$ & $*$ & $* * *$ & $* *$ & 23 & No recommendations \\
\hline Japan & $* *$ & $*$ & $* *$ & $* * *$ & $* *$ & 28 & $\begin{array}{c}\text { Water heaters, space } \\
\text { heating, home appliances }\end{array}$ \\
\hline South Korea & $* *$ & $*$ & $* *$ & $* * *$ & $* *$ & 17 & $\begin{array}{r}\text { Lighting, HVAC systems, } \\
\text { envelope insulation }\end{array}$ \\
\hline
\end{tabular}

ROW

\begin{tabular}{l|c|c|c|c|c|c|c}
\hline Russia & $* *$ & $*$ & $*$ & $* * *$ & $*$ & 47 & No recommendations \\
\hline Middle East & $*$ & $*$ & $*$ & $* * *$ & $* *$ & & No regional study found \\
\hline Australia & $* *$ & $*$ & $*$ & $* * *$ & - & 15 & HVAC systems, lighting \\
\hline
\end{tabular}

-Not implemented/no market.

* Initial market.

**Established market.

$* * *$ Mature market.

DG: double glazing, TG: triple glazing. 
controls the transfer of some or all of the following, depending on location, climate, and culture: heat, light, air, water, sound, fire, and inhabitants (safety), and the appropriate regulation of all of these factors is necessary to achieve a comfortable indoor environment. With respect to the energy usage of the building, the first three of those control functions, i.e., heat, light, and air, are the most relevant. Finally, the building envelope needs to satisfy aesthetic demands with respect to both external and internal surfaces. In the last few years, a fourth function of the building envelope has emerged, namely, (iv) the production of renewable energy through solar panels.

\section{Historical evolution of the building envelope}

The building envelope has always served the three main functions of structure, control, and aesthetics, but the construction techniques and materials have changed over the centuries. A good overview on the historical evolution of energyefficient buildings is given by Ionescu et al. ${ }^{34}$ The earliest known, earth-sheltered, green-roofed buildings from 5000 B.C. were found in a Neolithic village on the Orkney Islands, Scotland, and similar dwellings existed in other areas with a cold climate. ${ }^{35}$ In warm regions, already in 4000 B.C., the Persians used "wind towers" to lead cool air from underground water canals over the "building envelope". ${ }^{36}$ About 3100 B.C., ancient Egyptian builders used the insulating properties and heat capacity of thick brick walls to keep their buildings cool. They also made use of cavity walls for insulation-an approach that was later adopted by the ancient Greeks around 500 B.C. In Greece, the orientation of houses, the "Socratic house", usually was toward the South to gain solar energy. About a hundred years later, in 400 B.C., the Romans started to use wall heating, the so-called "hypocausts". ${ }^{34}$ Natural materials like reed, eelgrass, straw, etc., were used in many subsequent building styles to thermally separate the interior from the exterior. Thus, the main functional aspects of the envelope, namely, insulation, thermal mass, ventilation, and solar gains, were already established in antiquity. The next major conceptual advances came in the 19th century with the growing understanding of thermodynamics in terms of heat transfer and thermal insulation. These led to double pane windows as early as $1865,{ }^{37}$ the exploration of moisture transport in building elements in the 1890s, and the employment of the enthalpy-humidity diagram for the description of comfort zones in 1923. The first modern buildings focused on passive solar gains were built with the "House of Tomorrow" in $1933^{38}$ and the MIT Solar House \# 1 in 1939. ${ }^{39}$ The 1960s saw the advent of computer simulations to predict thermal load and performance of buildings ${ }^{40}$ as well as the seminal work of Povl Ole Fanger for the development of a standard thermal comfort model. ${ }^{41}$ The oil crisis in 1973 created a strong focus on building energy efficiency, taking into account air tightness, super-insulation [in the old sense of the definition as "extra thick insulation layers", the modern one referring to insulation materials with thermal conductivity values below $0.02 \mathrm{~W} /(\mathrm{m} \mathrm{K})]$, heat recovery ventilation, triple glazing, and passive solar technologies. The concept of a zero-energy house was explored by many prominent projects such as the "Phillips Experimental House" (1975), the DTH zero-energy house (1975), the "Lo-Cal House" (1976), and the "Leger House" (1977). ${ }^{34}$ Inspired by these advances, the idea of the "Passive House"-a building in which heat losses are reduced to a minimum by a highly insulated envelope-was developed in the late 1980s and implemented for the first time in the "Passive House Kranichstein" in 1991. ${ }^{42}$ Accompanying a high-performance building envelope with integrated photovoltaic panels and a seasonal energy storage, an energy-autonomous single-family house-the Self sufficient Solar House-was realized in 1992 in Freiburg. ${ }^{43}$ In 1995, "Passivhaus" became a standard in Germany for low-energy use buildings based on an air-tight, highly insulated thermal envelope in combination with mechanical heat recovery ventilation systems. Already a year earlier, a similar standard, the "Minergie" label, had been created in Switzerland.

\section{Construction techniques}

Construction types can be classified along a spectrum between monolithic and layered building elements, with hybrid construction types in between (Table 4). In the first case, the envelope or certain parts of it, for example, the walls, consist of one homogeneous material, at least on the macroscopic level. Common monolithic building materials are concrete, bricks, or solid wood. Usually, this monolithic structure accomplishes the two functions of structure and control at the same time and sometimes also the third function of aesthetics (e.g., fair-faced concrete, brick façade, or log house). In the complementary approach, the functionally layered construction, the structural and the control functions are realized as different layers, e.g., a concrete wall with a layer of insulation material on it and a separate air tightness membrane, as well as finishing layers on both sides. Between these two approaches, timber, steel, and concrete frame constructions are often hybrid constructions in which the building is neither layered nor monolithic. Here separate parts of the envelope take over structural and control functions, respectively, e.g., part of the wall is constituted of the load-bearing structure (e.g., a concrete column) and part is made of a wall material (e.g., curtain wall, bricks, concrete blocks, and a drywall). In some special cases of framing construction, though, the envelope is layered, namely, when the column is not integrated into the envelope but is further inside the building.

\section{Control functions and materials}

Let us now elaborate on the earlier introduced control functions of the building envelope in more detail in terms of the building elements and materials used. The transfer of heat is controlled either by the monolithic envelope or by a dedicated insulation material. Thermal transmission losses are determined not only by the insulation, i.e., the $U$-value of the construction, but also by how well the design avoids thermal bridges. This is especially important when superinsulating materials used as the insulation thicknesses are smaller and hence thermal 
Table 4. Different classical and contemporary construction styles.

\begin{tabular}{l|c|c} 
Monolithic constructions & Hybrid constructions & Functionally layered constructions \\
\hline Rammed earth & Timber frame (balloon, platform) & Concrete + insulation \\
\hline Solid wood & Steel frame & Brick + insulation \\
\hline Reinforced concrete (insulating) brick & Concrete frame & CLT + insulation \\
\hline
\end{tabular}

CLT: cross-laminated timber.

bridges have the potential to be more severe because of the shorter path lengths. Depending on climate conditions and optimization parameters (e.g., economical, ecological, energy or sustainability), different insulation thicknesses are optimal to reduce heating and cooling loads and the building operation cost. ${ }^{44-46}$ A comparison of conventional and superinsulation materials is given in the Conventional versus Superinsulation Materials section. Unlike opaque building elements, windows control both the flow of heat and of daylight, with the technology for switchable glazing emerging that limits light and/or energy transfer (see Window Technology and Solar Transmittance Control section). Furthermore, in both cold and hot climates, the flow of air through the building envelope should be minimized as cracks and leaks usually lead to unwanted heat losses or gains. ${ }^{47}$ Also, condensation and related damages can occur when warm air impinges on a cold part of a building element. Hence, airtightness is usually included in modern building standards and norms and is implemented technically in the form of different air and vapor barrier systems. ${ }^{48}$ Particularly in well-insulated airtight buildings, controlled ventilation systems are installed to allow for heat recovery from the expelled air to reduce the heating demand in cold climates ${ }^{49}$ and to increase the indoor air quality (IAQ). Depending on the climate and construction, e.g., roof overhang, the envelope also should be more or less waterproof, especially the roof. This is achieved by means of special coatings, renders, bituminous waterproofing, or ventilated façades or roofs of different materials (wood, ceramic, metal, rubber, etc.). Often times, façade and roof systems are not completely waterproof but are designed with a ventilation layer that allows for drying of the building materials after exposure to rain. Furthermore, the fire behavior of the different envelope materials is of crucial importance for safety in case of a fire. A discussion of the fire properties of the structural materials, which mostly fall into the category of nonflammable materials, is beyond the scope of this article. Many insulation materials on the other hand are flammable (Table 5) because they contain combustible organic compounds. ${ }^{50}$ In case of a fire, two main factors need to be considered: they contribute to the combustion load and thus accelerate the fire event and often produce toxic gases during burning, ${ }^{51}$ which is the main cause of fire-related deaths. Finally, regarding the function of controlling who or what can enter a building, with most of today's construction techniques, it is possible to design an envelope that offers relative safety against intrusion.

\section{Further envelope elements}

Apart from conventional opaque building elements and windows, there are a number of envelope elements that passively influence indoor comfort and save energy doing so. A good overview is given in Sadineni et al., ${ }^{47}$ describing passive solar walls, cavity walls, latent heat storage via phase change materials (PCM), ventilated roofs, cool roofs, green roofs, evaporative roof cooling, and photovoltaic roofs and façades. Passive solar or so-called Trombe walls consist of a massive South-facing wall with a glass pane in front to create a greenhouse effect and thus transfer heat into the building. In cavity walls on the other hand, the stack effect creates a vertical air flow, passively cooling the inner wall. PCMs have a high heat storage capacity and can be used for both passive cooling and heating applications, ${ }^{52}$ for example, in combination with a Trombe wall. Ventilated roofs have a cooling effect similar to cavity walls, reducing heat gains in warm seasons. Cool roofs serve the reduction of heat gains as well by using materials with high solar reflectance and high thermal emittance as a finishing layer to limit the amount of energy absorbed on the roof and maximize heat emissions. ${ }^{53}$ An alternative approach is a roof covered with plants, making use of the insulation effect of the soil-plant layer, the shading of the foliage as well as the evapo-transpiration of the leaves. Both mechanisms have been demonstrated to have a significant effect on estival heat gains. ${ }^{53-55}$ Green roofs have the added benefit of reducing water runoff from roofs as well as providing some thermal insulation in previously uninsulated roofs. ${ }^{56,57}$ This approach has also been successfully applied in façades, where similar cooling effects can be achieved. ${ }^{58,59}$ In tropical regions, a roof pond with removable insulation or wetted burlap bag covers can be used to reduce daily solar gains. ${ }^{47}$

\section{Thermal comfort}

Besides shelter from precipitation, wind, and solar irradiation, thermal comfort is certainly one of the main reasons why humans have been creating buildings to live and work in. Since the seminal work by Fanger in the $1960 \mathrm{~s},{ }^{41}$ thermal comfort models have been developed and used to quantify the satisfaction the building occupants with the interior environment conditions. These models are not only used to set the relevant building envelope parameters, such as insulation, acceptable window sizes, draft, etc., in the design phase of a building, but 
Table 5. Comparison of conventional and superinsulation materials.

\begin{tabular}{|c|c|c|c|c|c|}
\hline & $\begin{array}{l}\text { Thermal conductivity } \\
{[\mathrm{W} /(\mathrm{m} \mathrm{K})]}\end{array}$ & Combustible & $\operatorname{Max.} T\left[^{\circ} \mathrm{C}\right]$ & $\begin{array}{l}\text { Service } \\
\text { life [a] }\end{array}$ & $\begin{array}{l}\text { Material cost** } \\
{\left[\mathrm{US} \$ / \mathrm{m}^{3}\right]}\end{array}$ \\
\hline \multicolumn{6}{|l|}{ Conventional insulation } \\
\hline Mineral wool & $0.032-0.045$ & No & 600 & $>50$ & 120 \\
\hline Glass wool & $0.030-0.040$ & No & 400 & $>50$ & 120 \\
\hline Polystyrene foam & $0.029-0.037$ & Yes & 80 & $>30$ & 70 \\
\hline PUR/PIR foam & $0.021-0.025$ & Yes & 80 & $>30$ & 160 \\
\hline \multicolumn{6}{|l|}{ Superinsulation } \\
\hline Silica aerogel blanket & $0.015-0.018$ & No & $250 / 650^{*}$ & $>50$ & 3000 \\
\hline Silica aerogel granulate & $0.018-0.022$ & No & $250 / 650^{*}$ & $>50$ & 2800 \\
\hline Silica aerogel powder & $0.020-0.025$ & No & $250 / 650^{*}$ & $>50$ & 2500 \\
\hline Silica aerogel monolith & $0.012-0.014$ & No & $250 / 650^{*}$ & $>50$ & $(>10,000)$ \\
\hline PUR aerogel board & 0.017 & Yes & 150 & $>30$ & $(>4000)$ \\
\hline Fumed silica board & 0.019 & No & $250 / 900 *$ & $>30$ & 1500 \\
\hline Fumed silica core VIP & $0.006-0.009$ & Foil only & 50 & $>30$ & 4500 \\
\hline Glass fiber core VIP & № declaration values & Foil only & 50 & $>15$ & 2500 \\
\hline
\end{tabular}

*Loss of hydrophobicity above $\sim 300^{\circ} \mathrm{C}$.

**Estimated bulk retail pricing (2016).

also operational parameters of building HVAC systems during operation to achieve a high thermal comfort inside. Hence, thermal comfort models are fundamental for building design as well as energy consumption.

There are two different basic approaches to thermal comfort in buildings: the rational or heat balance and the adaptive approach, respectively. ${ }^{60}$ The former is based on experiments on human comfort in climate chambers in a steady state, most prominently represented by the work of Povl Ole Fanger. It employs a seven-point thermal sensation scale to determine the "Predicted Mean Vote" index, and from that the "Predicted Percentage Dissatisfied" is calculated-i.e., how many people will be dissatisfied under a given condition, including activity level, clothing, temperature, air speed, and relative humidity. This approach is suitable for steady-state conditions and humans in near sedentary activity levels. It works well in air-conditioned spaces, but not in naturally ventilated ones. ${ }^{61}$ Furthermore, the PMV seems to overestimate the thermal sensation in the tropics. ${ }^{62}$ The latter (adaptive approach) on the other hand is based on field studies on people in buildings and includes changes of activity level and clothing of building occupants in response to changes in the indoor environment. ${ }^{61}$ Recent research in the field has focused on thermal comfort in these transient conditions, identifying a high-energy saving potential as thermal comfort zones can be set less, restrictively. Adaptive approaches are also more suitable in tropical climates, where the PMV approach can lead to overcooling. Kwong et al. ${ }^{62}$ estimated that a $2 \mathrm{~K}$ rise in the thermostat set point in Malaysia would lead to $2150 \mathrm{GW}$ h of annual savings. A recent review of adaptive models can be found in Ref. 63 .

Yang and co-workers reported that adaptive thermal comfort models-which, especially for naturally ventilated buildings, describe comfort better than heat balance models-have a wider range of comfort temperature and could hence save a considerable amount of energy. ${ }^{61}$ Holopainen et al. studied three particular adaptive thermal comfort models, the adaptive predicted mean vote, a human thermal model, and the adaptive control algorithm, finding that all of these allowed for more flexible 
indoor conditions and hence lower energy use compared to heat balance models. ${ }^{64}$

\section{Indoor air quality}

A central aspect controlled by the building envelope that is not included in thermal comfort models is IAQ. Today it still seems to hold a secondary role to energy efficiency, but it is crucial to health, comfort, and productivity of building occupants. Overall, considerations of IAQ are not only relevant in countries with high technological standards but even more so in developing countries with more traditional construction and building operation approaches. In developing regions, indoor unvented burning of biomass leads to severe health effects and is still the fourth most important disease risk factor globally. ${ }^{65}$ In developed countries, on the other hand, while radon and tobacco smoke are linked to cancer, adverse effects of volatile organic compounds (VOCs), particles, allergens, and agents of microbial origin on human health are not well understood in terms of their mechanisms. ${ }^{66}$ Nevertheless, there is a high prevalence of allergies and sick building syndrome (SBS) in regions with modern, air-tight buildings. SBS denominates the acute negative effects on health and comfort connected to staying in a given building. There is strong evidence linking indoor IAQ to lung cancer, allergies, and hypersensitivity reactions. ${ }^{66}$ Additionally, perceived low IAQ is associated with SBS $^{67}$ even when controlled for other psychological factors. While it is not clear yet how VOCs, particles, and microbial matter influence health, an interventional study recently found that a reduction in particulate matter resulted in improved respiratory health. ${ }^{68}$ Also, ventilation rates have a significant influence on inhabitants' health. In their review, Sundell et al. ${ }^{69}$ found that higher ventilation rates of up to $25 \mathrm{~L} / \mathrm{s}$ per person lead to decreased inflammation, respiratory infections, asthma symptoms, and short-term sick leave. This ventilation rate is higher, though, than the required minimum of many building standards. Furthermore, dampness in buildings, increases the risk of adverse effects on the respiratory system, such as cough, wheeze, or asthma. ${ }^{70}$

Due to the insufficient IAQ not only health is affected but also comfort and work performance. In their review, Wargocki and co-workers ${ }^{71}$ found a strong association between ventilation, comfort, and productivity in office work environments. Maddalena et al. ${ }^{72}$ reported that for short exposures of four hours, perceived air quality and SBS symptoms were unaffected by ventilation rates, but reductions in ventilation rates had a significant negative effect on decision making abilities. Park and Yoon ${ }^{73}$ demonstrated a logarithmic increase in addition, text-typing, and memorization tasks when increasing ventilation rates from 5 to 10 and $20 \mathrm{~L} / \mathrm{s}$ per person for an eight hour observation period. In a review on studies on "average handling time" in call centers, a similar logarithmic association between ventilation rates and performance was revealed, ${ }^{74}$ leveling off at around $45 \mathrm{~L} / \mathrm{s}$ per person. Even a fifth grade student's academic achievement could be correlated to ventilation rates. ${ }^{75}$ In conclusion, proper ventilation of buildings is of crucial importance. Not only energy savings but also comfort, performance, and health needs are to be considered when designing ventilation systems and settings. Smart and demand-controlled strategies, e.g., via $\mathrm{CO}_{2}$-levels, seem to offer better solutions, as these can be more energy efficient allowing for high ventilation rates and thus high IAQ when it is actually needed. ${ }^{76}$

\section{Conventional versus superinsulation materials}

With increasing demands on thermal barrier properties of modern building envelopes, thicker insulation layers are needed. In some northern European countries, this has precipitated the use of up to $50 \mathrm{~cm}$ thick insulation which in some rare cases leads to wall strengths approximating $1 \mathrm{~m}$, closely reminiscent of a castle wall. Clearly this is no architect's dream. This is why we need insulating materials that offer superior thermal performance, i.e., superinsulation materials with a thermal conductivity $<0.020 \mathrm{~W} /(\mathrm{m} \mathrm{K}) .{ }^{77}$ Note that there exists an old definition of superinsulation corresponding to thick, conventional insulation (resulting in a low total $U$-value and high $R$-value), but in this article, we shall adhere to the modern, thermal conductivity-based definition.

\section{Historical evolution of insulation materials}

Over the last few decades, thermal insulation and hence insulation materials have gained critical importance for sustainable, energy-efficient buildings. Bozsaky ${ }^{35}$ reviewed the historical development of insulation materials and distinguished five time periods: (i) nomadic lifestyle and temporary buildings (before 7000 B.C.) where the same insulation materials were used for buildings as for clothing (animal skins, fur, and wool), (ii) preindustrial (7000 B.C. to 1870 A.D.) with durable materials (earth, wood, and bricks) or plant fibers (straw, eelgrass, and reed) as insulation materials, (iii) industrial (1870-1950) with natural insulation products (cellulose, boards from reed, cork, wood wool, and flax), advancement of bricks (ash-filled, hollow) and artificial mineral materials (asbestos, rock wool, fiber-glass, foam glass, dross, expanded clay, and perlite), (iv) plastics (1950-2000) with a variety of plastic foams (polystyrene, polyurethane, polyester, polyethylene, phenolic, and melamine based), and (v) sustainability and low-emission (since 2000) with a revival of natural materials like cellulose, cork, etc. and exploration of new high-performance materials such as vacuum panels or aerogel materials. Thus, today, building professionals have a wide selection of insulation materials at hand, with different properties and environmental impacts, allowing for the construction of highly insulated new buildings and the renovation of existing ones in a flexible fashion.

\section{Conventional insulation materials}

An overview of insulating materials and products is given in Table 5. Conventional materials feature thermal conductivities between 0.03 and $0.04 \mathrm{~W} /(\mathrm{m} \mathrm{K})$ with the exception of polyisocyanate foams (PU, PIR and PUR), which achieve lower thermal conductivities through the use of a heavy, low thermal conductivity filler gas inside the closed-cell network, e.g., a mixture of 
$\mathrm{CO}_{2}$ and iso- or cyclopentane. Next to these standard products, there exists a variety of insulation materials derived from natural products, e.g., straw, reed, eelgrass, cellulose fiber-based materials, animal furs, sheep wool etc., or inorganic materials, e.g., foam glass, foamed clay, pumice etc. These materials are attractive from an embodied energy perspective but suffer from significantly higher thermal conductivities. Modern construction in first and second world countries nowadays are insulated primarily with polymer foams and glass or mineral wool $(>90 \%$ market share). ${ }^{78}$ These products are durable, low-cost commodities with the best price per performance ratio. Polymer foams (EPS, PU/PIR/PUR) are intrinsically flammable which negatively affects fire ratings, and environmental concerns have been raised for classes of flame-retardant additives. ${ }^{79}$ Other insulation strategies do not use a separate material for insulation but modify the properties of the load-bearing envelope materials, for example, the addition of cenospheres to concrete to decrease weight and thermal conductivity. ${ }^{80}$

\section{Superinsulation materials and products}

The class of superinsulators consists primarily of fumed silica, aerogel-based materials, and vacuum insulation panels (VIP). More recently, people have also started to investigate gas-filled panels as a possible building insulation solution; however, no superinsulating products of this type are yet available commercially, partly due to the high cost of ultralow thermal conductivity filler gases such as krypton. ${ }^{81}$ VIP and aerogelbased superinsulating materials and solutions have been on the market for roughly 10-15 years. These products offer superior performance (very low thermal conductivity) but are more expensive than conventional insulation to reach the same insulation performance ( $U$-value). Fumed silica, aerogel, and VIP are known and established niche products in the building and construction industry, but their market share is below $1 \%$ of the total market. ${ }^{77}$ In Europe, aerogel insulation sales for building applications are estimated to lie within the $25-30 \mathrm{M}$ US $\$$ range for 2016. For the same year, the global aerogel market is roughly $250 \mathrm{M}$ US $\$$, which is on the order of $0.5 \%$ of global insulation markets which are estimated at 45B US $\$ .{ }^{78}$ Vacuum insulation markets are of a similar magnitude with 2014 sales on the order of $380 \mathrm{M}$ US $\$^{82}$ of which roughly $15 \%$ of it are used in the building and construction sector. Both aerogel and VIP markets are growing rapidly at a CAGR of approximately $20 \%$.

Superinsulation materials come in many forms: VIPs, monolithic aerogels, silica aerogel granulate, blankets, boards, and paste-like wet mix formulations such as insulating renders (Fig. 1). Most of the development on VIPs is on less expensive core materials, ${ }^{83}$ where the main challenge is to match thermal and service life performance of traditional fumed silica cores [Fig. 1(a)]. ${ }^{84}$ Monolithic aerogels are not yet commercially available due to high production cost, although BASF is in the process of scaling up Slentite, which may well be the first commercial polyisocyanate aerogel insulation product [Fig. 1(b)]. Aerogel granulate and blankets are today’s most viable industrial materials. Cabot aerogel is manufacturing hydrophobic, silica aerogel granulates [Fig. 1(c)], and the aerogel market leader Aspen aerogels produces blanket-type products such as Spaceloft [Fig. 1(d)]. Both product types are rarely used as-is on the construction site but are typically converted into a (semi-) finished product or solution which will then be applied or installed at the building site. Two examples of such aerogelbased products are aerogel insulation boards, e.g., Heck Aero obtained by gluing several Spaceloft blankets together, or a wet applied high-performance render which was especially developed for retrofitting old historical buildings. ${ }^{85}$ Aerogel renders are insulating render systems which contain a large volume
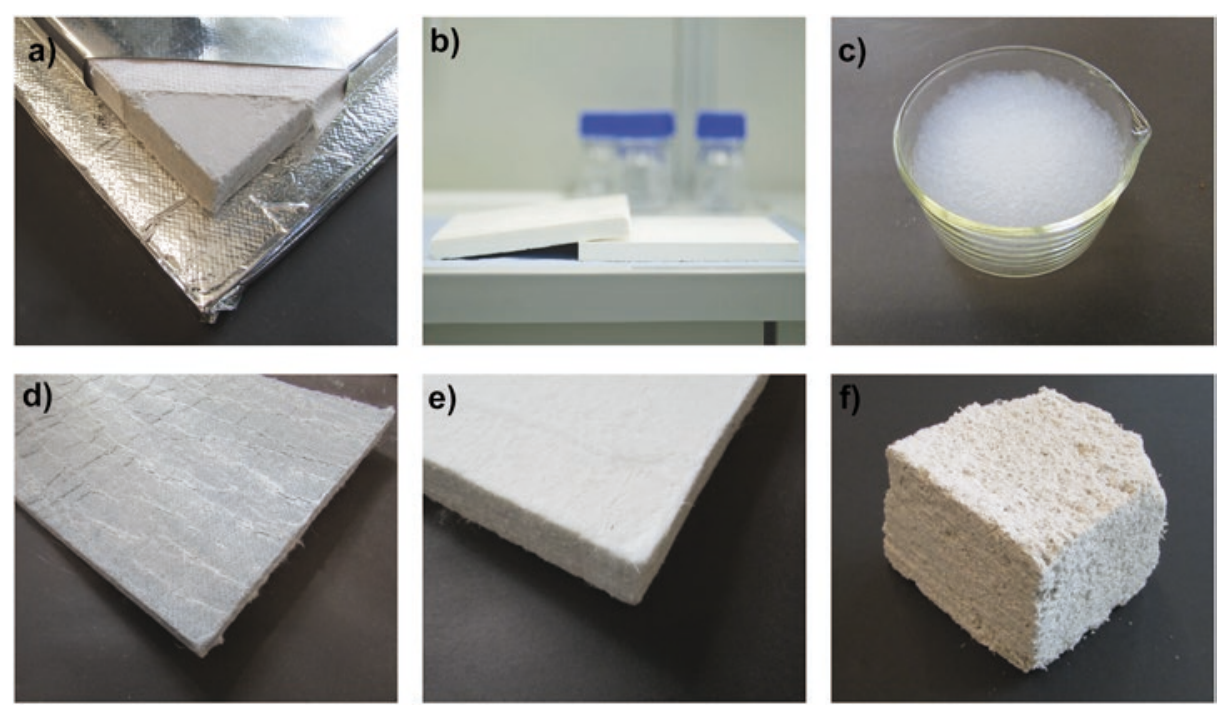

Figure 1. (a) Cross section of a vacuum insulation panel, (b) monolithic aerogel board (courtesy of BASF), (c) silica aerogel granulate, (d) silica aerogel blanket, (e) silica aerogel board, and (f) silica aerogel render. 
fraction of aerogel granulates as a low thermal conductivity filler. They are sold in bags as a dry mix formulation containing mineral binders and additives, allowing facile on-site mixing with water and direct application on the façade using conventional render projection pumps. Other granulate-based composite materials such as aerogel concrete ${ }^{86}$ or glued composites are also under development.

The use of superinsulating materials today is still very restricted in the $\mathrm{B} \& \mathrm{C}$ sector due to the high price, low innovation dynamics of the sector, and large number of stakeholders involved in the construction process. However it is clear that urbanization and energy policy are huge drivers for the commercialization of superinsulation materials and solutions on a broader front. To accomplish this, improved production methods combined with the economy of scale must bring down prices, innovative products which combine all advantages of superinsulation must facilitate installation and market entry, and communication efforts must educate and inform stakeholders about these new possibilities.

\section{Window technology and solar transmittance control}

Windows visually connect the building interior to the outside world and provide a functional and pleasant indoor environment. The effect of windows on the energy performance of the façade is complex: the thermal transmittance of windows, i.e., the $U$-values, are typically two to five times higher than for other façade elements, but the resulting heat losses are typically more than offset by solar gains, expressed by the $g$-value or Solar Heat Gain Coefficient of a given glazing unit. ${ }^{87}$

\section{Heat losses (U-value)}

The last six decades have seen a five to ten-fold reduction in the $U$-values of glazing solutions through a variety of technological cornerstone developments. The introduction of double glazing in the 1950 s lead to nearly a two-fold reduction of the

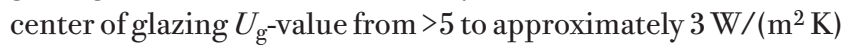
and marks the start of insulation glazing as a research field. Over the next forty years, the industry again made tremendous progress by introducing low-emissivity (low-E) coatings and argon as a filler gas as well as the introduction of triple glazing. The introduction of low-emissivity (low-E) coatings, which are now standard in modern insulated glazing, led to the most dramatic improvement of the glazing's thermal properties, allowing a reduction of the radiative thermal conductance due to radiation from approximately 1.5 down to $0.1 \mathrm{~W} /\left(\mathrm{m}^{2} \mathrm{~K}\right) .{ }^{88,89}$ The use of mono-atomic filler gasses with lower thermal conductivity also leads to a significant reduction in the $U_{\mathrm{g} \text {-value: }}$ replacing air by argon results in a reduction of approximately $0.5 \mathrm{~W} /\left(\mathrm{m}^{2} \mathrm{~K}\right)$, and the use of krypton or xenon can further reduce this by an additional $0.2-0.3 \mathrm{~W} /\left(\mathrm{m}^{2} \mathrm{~K}\right)$, respectively. ${ }^{88}$ Based on cost and availability, argon is by far the preferred filler gas, whereas krypton is limited to high-end products only. As the center of glazing $U_{\mathrm{g}^{\text {-values }}}$ improved due to the use of low-E coatings and low-conductivity filler gases, heat losses through the edge have gained relative importance. Significant improvements have been achieved by optimizing spacer materials and design: replacing aluminum spacers for stainless steel, foam, and thermoplastic spacers and optimizing the spacer geometry results in a significant reduction of these edge effects. ${ }^{90,91}$ Further improvements have come from optimizing the design and materials of the sash-and-frame construction in terms of thermal conductivity. ${ }^{92}$ Note that the degree to which the various technologies have been adopted varies wildly depending on region, country, building norms, purchasing power, climate, and environmental awareness. Europe is leading the way with respect to market uptake: advanced insulated glazing with argon filling, high-performance low-E coatings, and optimized spacer and sash-and-frame designs with $U_{\mathrm{w}}$-values for the entire window around $\sim 1.1$ and $\sim 0.6 \mathrm{~W} /\left(\mathrm{m}^{2} \mathrm{~K}\right)$ for double and triple glazing, respectively, are now the standard solution.

In addition to the above-described mainstream developments, even higher performant glazing elements are available for niche markets. The addition of a fourth layer of glazing further lowers the $U$-value, but such products have not made an impact in the market due to the high cost-to-benefit ratio, high weight, and increased thickness. ${ }^{93}$ More innovative solutions along this line are the use of thin glazing layers in quadruple glazing or polymer film multi-chamber glazing units. ${ }^{94}$ Vacuum insulation glazing (VIG) approaches the problem differently and eliminates the gas phase conductance altogether but requires stringent criteria on the edge seal and the use of support pillars to keep the panes apart, resisting against the outside atmospheric pressure.$^{95-97}$ In theory, $U$-values down to $0.3 \mathrm{~W} /\left(\mathrm{m}^{2} \mathrm{~K}\right)$ can be achieved with a single VIG. Vacuum glazing products have been on the market for several decades now, but in general, their performance is poor [between 0.5 and $1.1 \mathrm{~W} /\left(\mathrm{m}^{2} \mathrm{~K}\right)$ ] when measured against theoretical limitations, barely keeping up with state-of-the-art triple glazing in terms of $U$-value. Their commercial success will eventually rely on the thin design, although recent developments by new Chinese manufacturers ${ }^{96}$ claim products with $U$-values $<0.6 \mathrm{~W} /\left(\mathrm{m}^{2} \mathrm{~K}\right)$. It is the slim design $(<10 \mathrm{~mm}$ ) which enables retrofitting of existing frames in historical buildings by directly replacing single-paned glass by VIG, providing excellent thermal and sound insulation properties, which is highly desirable for inner-city applications. Transparent aerogel glazing can achieve $U$-values below $0.7 \mathrm{~W} /\left(\mathrm{m}^{2} \mathrm{~K}\right)$ for a glazing thickness below $15 \mathrm{~mm}$ at the prototype level, ${ }^{98-100}$ but upscaling and product development using this technology are challenging at a laboratory scale and are virtually impossible at an industrial scale due to the brittleness of the aerogel. Translucent aerogel elements for daylighting applications that typically consist of a cavity filled with aerogel granulates ${ }^{98,101}$ have been introduced in the market, and $U$-values from 0.3 to $0.6 \mathrm{~W} /\left(\mathrm{m}^{2} \mathrm{~K}\right)$ can be achieved depending on thickness, with an optical transmittance of $45-60 \%$.

\section{Solar gains and solar control (g-value)}

Due to their transparent nature, windows' high heat losses are offset, by solar gains and windows with a high $g$-value, i.e., with a high solar energy transmittance, can strongly decrease 
the heating demand. However, solar gain control is required to provide glare protection and avoid overheating during warm and hot periods, even though the energy reflected back to the environment may increase the heat island effect. Passive solar control measures include the use anti-reflective (low-emissivity) coatings ${ }^{102}$ and angular selective window systems that differentially reflect the sunlight depending on the incidence angle. ${ }^{103,104}$ The traditional and most straightforward way to actively control solar gains is by external blinds and this is by far for the most implemented solution. However, external blinds are prone to wind or hail damage and their installation and maintenance cost can be substantial. From a materials science perspective, switchable glazing is a highly attractive form of active solar control. ${ }^{105}$ Here, the optical transmission and solar gain can be switched between a bleached and darkened state by changing the redox state of a thin active material layer. Depending on the stimulus, this can be a form of active solar control, e.g., electrochromic ${ }^{106}$ and gasochromic $^{107}$ glazing or passive solar control, e.g., photochromic ${ }^{108}$ and thermochromic ${ }^{109}$ glazing. All of these are active areas of scientific research, but electrochromic glazing based on tungsten oxide, $\mathrm{WO}_{3}$, (Fig. 2) has been most successful in the market. ${ }^{106}$ Academic and industrial research actively pursues improved performance by changing from liquid based to solid state electrolytes and optimizing the electrochromic material film properties, e.g., by improving the sputter-deposition, sol-gel synthesis, ${ }^{110}$ and vapor deposition, ${ }^{111}$ the quest for alternatives to $\mathrm{WO}_{3}$ such as $\mathrm{VO}_{2} / \mathrm{V}_{2} \mathrm{O}_{5}{ }^{112}$ or $\mathrm{NiO}$, ${ }^{113}$ the use of polymer electrolytes ${ }^{114,115}$ or the development of infrared selective devices. ${ }^{116}$ Other proposed active solar gain control measures include the use of circulating suspensions of light absorbers, where active control is achieved by tuning the particle concentration, e.g., FluidGlass. ${ }^{117}$ Active solar gain control systems can be operated manually, i.e., at the discretion of the building occupant, or automatically. Together with controlled ventilation, automated solar gain control is one of the key components that allows the building energy management system to dynamically respond to the user demands and weather conditions (see also "Dynamic Behavior, Building Energy Management and Smart Grids” Section).

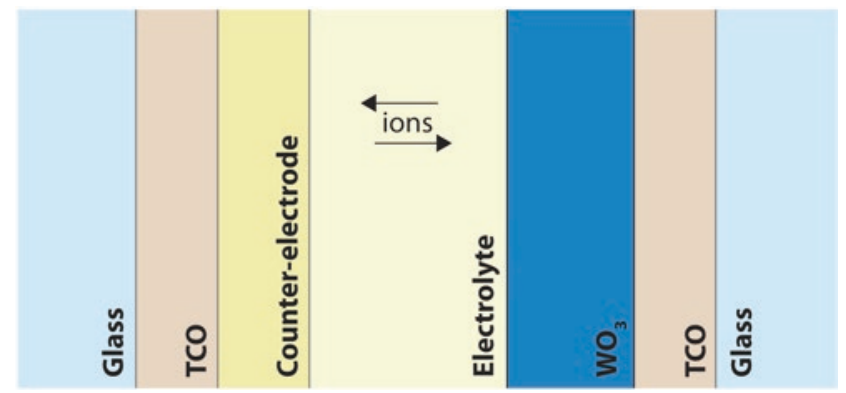

Figure 2. Schematic cross section of $\mathrm{WO}_{3}$ based electrochromic glazing. The coloration of the electrochromic layer can be tuned by switching the redox state of the active electrochromic material layer, most typically $\mathrm{WO}_{3}$. The current is provided through a transparent conductive oxide layer (TCO). The device design is an electrochemical cell similar to a battery.

\section{Lighting}

Incandescent lighting has had a tremendous impact on the society, so much so that the image of a light bulb has become synonymous with a good idea, and Thomas Edison has become the archetypal inventor in popular culture. Indeed, incandescent lighting has been the standard technology for nearly the entire 20th century. Standard incandescent light sources have a luminous efficacy of approximately $15 \mathrm{~lm} / \mathrm{W}$. Halogen incandescent bulbs have been available since the 1950s and have now an efficacy on the order of $30 \mathrm{~lm} / \mathrm{W}$. Fluorescent lights (TL) have a much higher efficiency on the order of 25-95 lm/W. Commercially available light emitting diodes (LEDs) already achieve a higher efficacy than that of the fluorescent tubes (up to $130 \mathrm{~lm} / \mathrm{W}$ ) with a theoretical limit of 260-300 lm/W.118,119 The rate of progress in this field is remarkable not only with respect to the development of more efficient LEDs but also with respect to their adoption in the market place. Their low efficacy has finally caught up with incandescent lighting, and incandescent light bulbs have even been banned for most uses by the European Union. The energy consumption due to lighting has decreased substantially over the last two decades, with, for example, a drop from 38 to $17 \%$ in the share of lighting to the overall electricity consumption of commercial buildings. ${ }^{120}$ These savings are not only related to the above-described efficiency increase of the light sources but also to the reduced wastage, for example, by automatically switching of the lights when a space is not occupied and a better use of natural daylight through better architectural planning. Research on improved light sources, buildings and illumination automation, and architectural solutions to daylighting is ongoing, but the advances made over the last decades have already reduced the impact of lighting on the overall energy budget of buildings.

\section{Renewable energy}

Once the building envelope is brought up to a certain thermal standard, it is easier to cover the remaining energy demand from renewable sources. To become fit for the future, buildings must produce a significant fraction of their demand themselves. Solar energy is by far the most common renewable energy source for buildings through the use of solar thermal collectors, photovoltaics, and hybrid ${ }^{121}$ elements, where the market share of the latter remains comparatively small.

\section{Solar thermal collectors}

Solar thermal collector technology is a rather mature field, and solutions with various degrees of technical complexity are on the market. ${ }^{122}$ Selective absorbers increase the operating temperature by having a high ratio of solar radiation absorption to thermal radiation emission. ${ }^{123}$ Building integrated modules are typically nonconcentrating collectors, with the same intercepting area as its absorbing area. Concentrating collectors, which focus the solar irradiation of a large intercepting area onto a small absorbing area using concave mirrors, can achieve much higher fluid temperatures and Carnot efficiencies but are much less common in buildings. Among the nonconcentrating 
collectors, flat-plate collectors, which exist for over a hundred years, are most commonly used. They consist of an absorber (e.g., a painted copper plate) which is welded to a copper pipe that acts as the heat transport vehicle. The absorber is then enclosed inside an insulated metal trough which is in turn covered by a cover glass. Evacuated tube collectors are a more recent development with first products appearing on the market after the first oil crisis in the seventies. A typical device uses a central copper pipe with absorber fins which is welded into an evacuated glass tube. The glass tube itself is typically a doublewalled vessel which is also evacuated and sealed, resulting in minimized heat losses through gas conduction, the same principle which VIPs and vacuum glazing are based on. As a result of the lower heat losses, a higher working fluid temperature can be achieved. In addition, the specific geometry results in the exposure of the absorber to the sunlight for a longer period of the day. ${ }^{124}$ Flat-plate collectors are the solution of choice for a majority of climates and user profiles as they are roughly $30-40 \%$ cheaper than tube collectors for the same installed power. Vacuum tube collectors make sense in very cold climates, although they are slow to shed a possible snow cover and for applications where a higher medium temperature is required. Very often, solar thermal collectors are combined with heat pumps and/or underground thermal energy storage systems. ${ }^{125,126}$

\section{Building integrated photovoltaics (BIPV)}

The development of new solar cell materials is a very active area of research and is out of the scope of this review. Record efficiencies for single-junction, single-crystal and multicrystalline silicon are currently around 25 and $21 \%$, respectively, ${ }^{127}$ and silicon is by far the most widely used material. The performance, in terms of efficiency, of thin film cells (GaAs, CdTe, CIGS), multijunction devices (InGaP/GaAs/InGaAs) can be higher than that of silicon, but at the moment, none of these materials have made an impact in the building and construction sector. Following a continuous and dramatic reduction in cost (Moore's law behavior), silicon solar panels have become a commodity and installation, rather than materials, now make up the vast majority of the total cost. Historically, solar panels have been added on top of an existing building envelope almost as an afterthought. In contrast to these building-adopted photovoltaics, building-integrated photovoltaics are an integral part of the building envelope, offering weather protection as well as aesthetic function. ${ }^{128,129}$ This double function as an energy producer and the building skin makes BIPV more cost effective because other cladding materials are no longer needed ${ }^{130-132}$ and new possibilities for the aesthetics of photovoltaics have been developed. ${ }^{130}$ The vast majority of photovoltaics are installed on the roof, but various solutions for the façade are available. In the summer, the amount of solar irradiation reaching the façade is lower than that of the roofs, as expected, but due to the large areas concerned, facades can contribute significantly to the solar potential of buildings, depending on climate, building geometry, and orientation. ${ }^{133}$ In the winter, on the other hand, façade BIPVs can have higher output than that of PV on the roof due to the lower position of the sun. The emergence of printable PV technologies opens up renewed opportunities for building integration. ${ }^{134}$

\section{Thermal storage and sorption cooling}

\section{Thermal storage}

The ability to store energy in various forms for delayed or distributed use is a topic of increasing actuality. The key parameters defining energy storage systems are the storage time period, capacity, and cost. To cover the daily fluctuations in thermal energy demand (hot water), a storage period of a few days and a relatively small capacity are sufficient. The most straightforward way to store thermal energy is in the form of sensible heat, i.e., by capitalizing on the heat capacity of a given storage medium. Hot water reservoirs or boilers are the classical example for this type of simple solution. Long-term seasonal storage of thermal energy for low-temperature (e.g., floor heating) systems is relatively costly and requires large water storage volumes when operated exclusively on a sensible heat principle. For well-insulated low-energy buildings $\left[U_{\text {wall }}<0.15 \mathrm{~W} /\left(\mathrm{m}^{2} \mathrm{~K}\right)\right.$, triple glazing], the heating demand during the winter season in central Europe can be covered with a typical water reservoir on the order of 20-50 $\mathrm{m}^{3}$. Around the turn of the millennium, several experimental large thermal storages have been realized and tested with solar thermal collector areas up to $5000 \mathrm{~m}^{2}$ and water storage reservoirs up to $12,000 \mathrm{~m}^{3}$ in size. ${ }^{135} \mathrm{~A}$ more recent trend is to use the ground as a thermal energy store and deposit excess thermal energy into geothermal boreholes either directly or, preferably, through a conventional heat pump system. ${ }^{136,137}$

Latent heat storage uses the enthalpy of fusion or evaporation of a storage medium and is a promising alternative to sensible heat storage, especially if the space is limited. It offers a 2-5 times higher volumetric energy storage density (Table 6) and furthermore delivers the thermal energy at a constant temperature level, i.e., at the specific phase transition temperature of the storage medium, rather than at progressively lower temperatures such as in the case of a sensible heat storage system. Both liquid and solid latent heat storage materials and systems are known. Latent, seasonal heat storage devices could offer significant potential to reduce the heating demand in colder climates with reduced space demand. Pure latent heat storage devices work at a constant composition/mass, the typical example being phase change material (PCM) storage. ${ }^{138}$

Alternatively, thermochemical storage involves the storage and release of thermal energy in a chemical form, e.g., salt hydration or water sorption which means a sorbent or "reagent" is added thus changing the mass and composition. Such systems have received increasing attention for their potential use as space-saving, seasonal heat storage solutions. For example, a novel promising system currently under development at our institute (Empa) is a high ettringite CSA solid cement system which uses hydration/dehydration of ettringite type phases that offers up to $500 \mathrm{MJ} / \mathrm{m}^{3}$ storage capacity in a temperature 
Table 6. Overview of common heat storage materials. ${ }^{138,139}$

Storage capacity

\begin{tabular}{|c|c|c|c|c|}
\hline Materials & $T$ range $\left[{ }^{\circ} \mathrm{C}\right]$ & {$[\mathrm{kJ} / \mathrm{kg}]$} & {$\left[\mathrm{MJ} / \mathrm{m}^{3}\right]$} & Typical implementation \\
\hline \multicolumn{5}{|l|}{ Based on heat capacity } \\
\hline Water (for $\Delta T=30^{\circ} \mathrm{C}$ ) & $0-100$ & 126 & 126 & Tanks, borehole storage \\
\hline Granite (for $\Delta T=30^{\circ} \mathrm{C}$ ) & $10-200$ & 24 & 65 & Borehole storage \\
\hline \multicolumn{5}{|l|}{ Based on heat of fusion } \\
\hline Water-ice & 0 & 334 & 334 & Ice/water tank \\
\hline Salts and salt hydrates & $8-900$ & $125-450$ & $250-900$ & Building integrated PCM \\
\hline Hydrocarbons & $4-140$ & $90-250$ & $90-200$ & Building integrated PCM \\
\hline \multicolumn{5}{|l|}{ Thermochemical storage } \\
\hline Ettringite cement (de)hydration & $40-120$ & 250 & 500 & Under development \\
\hline $\mathrm{NaOH}$ dilution/concentration & $10-50$ & 900 & 1350 & Under development \\
\hline
\end{tabular}

range between 40 and $120{ }^{\circ} \mathrm{C}$ with material cost comparable to other types of high-performance concrete. ${ }^{139}$ Other types of more classical solid thermochemical energy storage systems (zeolites, silica gels, hybrid zeolite/salt systems) have also been studied for seasonal heat storage ${ }^{140,141}$ with storage energy densities similar to that of the ettringite but at a higher materials cost. Even higher storage densities are possible when a dilution or sorption process is combined with the condensation of the sorbate. When using an aqueous system, for example, one can then capitalize on the latent heat of water evaporation/ condensation by operating in a partial vacuum. One of the more promising systems in this category uses a concentrated sodium hydroxide solution, ${ }^{142}$ which stores its energy in the form of potential dilution and latent heat of water vapor condensation (added later during the discharging cycle). This latter system offers a very high theoretical storage density up to $1350 \mathrm{MJ} / \mathrm{m}^{3}$. ${ }^{143}$

By far, the most common use of latent heat storage materials at the single building level is the incorporation of PCMs into the building envelope. Selected application examples have been discussed in the building envelope section. In this way, thermal energy can be stored during the daytime (solar gains) and released during the night thus reducing the heating demand during wintertime. Typically the active temperature window of a PCM material is rather narrow and must be adapted to a specific building/use case scenario since it corresponds to a phase transition (melting/solidification) with a well-defined temperature level. Generally, two types of compounds are used as the active material, namely salt hydrates (potassium fluoride, calcium chloride) and "wax-like" long chain fatty acids and hydrocarbons (butyl stearate, octadecane, propyl palmitate etc.). Mixtures are often used to adjust the melting point to the specific application needs. Typical heats of fusion of PCMs are in the $150-200 \mathrm{~kJ} / \mathrm{kg}$ range. ${ }^{144}$ Note that the organic, hydrocarbon-based PCMs are highly flammable which may render building integration challenging. Much of today's research \& demonstration activities are centered on encapsulation, packaging, and integration into building components and architectural elements. The development and testing of PCMs for building applications have been a topic of great research activity in the past twenty years, ${ }^{144-146}$ but the market uptake in the built environment is still rather hesitant.

\section{Heating systems}

Despite advances in envelope performance, including the optimized use of solar gains (see above), most buildings in cold and temperate climates require active heating during winter and hot water supply around the year. For highly-insulated buildings, the energy needed to provide hot water can even become the dominant part of the overall yearly energy demand. The most common heat sources for buildings fall into one of the three categories of combustion, heat pumps, and solar thermal. Electric direct heating is very inefficient in terms of primary energy and hence will not be discussed in the following. Combustion heating systems for buildings are typically based on oil, gas, or coal as nonrenewable energy sources with wood as a renewable alternative. The most common heat pump systems 
for buildings are brine-water, air-water, and water-water systems. Brine-water systems are usually operated as ground-coupled heat pumps, i.e., heat is extracted from the ground and transferred to water used for heating. For that, brine is circulated either in vertical, $\mathrm{u}$-shaped pipes in ground boreholes of depths between 50 and $300 \mathrm{~m}$, where the ground temperature is more or less constant all year long or in horizontal pipe arrangements at a depth of about 1-4 m, where the ground temperature is dominated by solar irradiation and precipitation and hence varies with the seasons. ${ }^{147}$ The second approach is usually more cost-effective but can only be used if sufficient space is available around the building and hence is not well suited in cities. In water-water heat pump systems, flowing water, often times ground water, is used as the heat source; whereas, in air-water systems, heat is extracted from the surrounding air. There are also hybrid systems, which combine, for example, a groundcoupled heat pump with an air heat pump or a solar collector system. ${ }^{126,148}$ With ground-coupled heat pumps, depletion of the ground heat can occur after a few years, so a so-called thermal "regeneration" of the soil surrounding the borehole might become necessary. This can be achieved by circulating warm water from solar collectors in the borehole ${ }^{126}$ or by using the borehole as a heat sink for building cooling. ${ }^{148}$ Finally, solar thermal systems can be used to provide hot water and heating. Depending on the solar irradiation in the winter, these systems can be either used as an additional heat source, in combination with a heat pump system, or as the main heat source in combination with seasonal heat storage.

The presented systems can be evaluated with respect to costsinstallation and operation-environmental impact, availability, and compatibility with the planned or already available heat delivery system to find an optimized solution for a given building. An evaluation of the cost of the different systems is beyond this discussion because cost strongly depends on location, and future trends are hard to predict. With respect to environmental impact, fossil fuels are characterized by high net $\mathrm{CO}_{2}$ emissions; whereas, the $\mathrm{CO}_{2}$ impact is considerably lower for wood fuels. ${ }^{149}$ Other emissions and their toxicological impact depend on the type of wood fuel and can be minimized by filtration to levels below those of oil combustion. ${ }^{150,151}$ For heat pump systems, the environmental impact depends on the coefficient of performance (COP) and on how the electricity they consume is generated. If renewable sources of electricity are used, heat pumps have a low-environmental-impact. Solar heat systems generally have a very low environmental impact. ${ }^{152}$ While combustion heating systems are widely available, ground-coupled and water-coupled heat pump systems cannot be used in every location, and air-air heat pumps can be problematic due to noise emissions. The feasibility of solar thermal heating systems depends on the climatic conditions. Finally, the heat delivery system limits how efficiently the generated heat can be distributed. Radiators require highflow temperatures $\left(\sim 60^{\circ} \mathrm{C}\right)$ and thus favor the use of combustion heating as heat pumps are not very effective for such high temperature differences. Floor or wall heating, on the other hand, can be operated at considerably lower temperatures $\left(\sim 30^{\circ} \mathrm{C}\right)$ and also heat pumps and solar thermal are effective in these cases.
Finally, it should be noted that the discussed heating systems can also be implemented on a larger scale as district heatingusually with corresponding increases in efficiency and reduction in emissions for combustion systems. Furthermore, in district heating plants, other combustion fuels can be used, and the waste heat of industrial processes can be utilized. Hence, district heating often offers a low-environmental-impact heat supply.

\section{Sorption cooling}

With increasing global temperatures and comfort needs, cooling and dehumidification demands are expected to rise roughly ten-fold by 2050 from today's level, whereas the heating demand will plateau. ${ }^{153}$ At the same, a recent review estimates the global waste heat at "low"-temperature levels below $100{ }^{\circ} \mathrm{C}$ at $156,000 \mathrm{PJ}^{154}$ or roughly $27 \%$ of the global energy consumption. For waste heat at low temperatures, carnotization, e.g., the conversion into other energy forms using, for example, a steam turbine, is clearly inefficient and the tremendous pool of unused waste heat is contrasted by the lack of suitable use scenarios. "Thermally driven" sorption heat pumps are flexible and scalable (from $\mathrm{kW}$ to MW power) systems which allow facile valorization of waste heat or solar thermal energy and thus offer a unique way to make better use of untapped thermal energy sources. More specifically, sorption heat pumps can be used to convert currently worthless, low-grade heat into precious cooling power with a COP around 0.5-0.6, potentially massively contributing to reducing the global electricity consumption. In a second mode of operation, sorption heat pumps can upgrade waste heat from a higher to a lower temperature level to provide the warm water required for low-temperature floor heating in buildings with a COP around 1.5.

Sorption heat pumps with liquid sorbents such as alcoholwater, ammonia etc. have been widely studied. ${ }^{155-157}$ More recently, solid sorbents have been investigated due to the significantly lower cycled thermal mass. ${ }^{158,159}$ In comparison with a conventional heat pump in which a mechanical compressor drives the cycle, adsorption heat pumps make use of adsorption/ desorption cycles of a sorbate, most often water, onto a porous solid sorbent to provide a temperature lift. Current R\&D is targeting primarily the development of more efficient sorbents with tailored hierarchical porosity as well as a heat exchanger design and fast/smart assembly techniques. Preferred materials $^{160}$ have steep, step-like adsorption isotherms in the application-relevant pressure range relevant to maximize the amount of cycled adsorbate. Adsorption heat pumps are commercially available from a few suppliers worldwide, but significant improvements in their efficiency and space requirements are needed to allow a more widespread market penetration. Innovative manufacturers such as Sortech in Germany have recently developed the so-called hybrid compressor driven/sorption heat pump machines which offer added flexibility and extremely high efficiency under a partial cooling load.

In conclusion, thermal storage and adsorption cooling are not yet widely implemented, primarily due to the low energy 
cost, comparably high initial investment, and long payback times of such solutions. Nevertheless, technologies focusing on more efficient usage of waste heat such as seasonal storage and thermally driven heat pumps are expected to play an important role in energy networks at the district and energy hub scale as well as at the cradle, the producer of thermal waste heat, in the coming decade.

\section{Electrical energy storage}

In the previous section, we emphasized the ability of thermal technologies to reduce the electrical demands for heating and cooling. With the installation and production of renewable energy sources on the rise, temporal production-demand matching is recognized as the central challenge. Undisputedly, battery storage can increase the photovoltaic self-consumption in buildings. ${ }^{161}$ Various types of electrical energy storage solutions exist which can be used from a single building $(\mathrm{kW} \mathrm{h})$ to district (MW h) to megacity (GW h) scale. ${ }^{162}$ Energy storage solutions combined with energy district networks and smart grids are likely to see a massive increase in implementation in the coming decades. Amongst all the direct electrical energy storage systems, the most relevant ones for the built environment are those with an intermediate storage period on the order of hours to single days. In the following, we shall briefly sketch available technologies in the order of decreasing the storage capacity.

Highest capacity and low-cost, low-tech, easy to implement solutions are based on mechanical potential energy storage. Hydropower pump storage systems are typically massive installations in the 500-15,000 MW h capacity range which are used as large scale buffers for the electric grid and are not of specific relevance to the built environment. ${ }^{163}$ Compressed air storage (CAES) employs underground caverns as reservoirs to deposit and release pressurized air which is then converted to mechanical/ electrical energy through a compressor/turbine assembly. ${ }^{164}$ Typical installations are of medium to high capacity in the low GW h range. Storage times of several hours to one day are typical and determined by the ratio of volume to total leakage of the cavern system. Until now, several CAES pilot projects have been realized. The overall storage efficiency depends on the type of gas expansion process, with the most advanced adiabatic concepts such as ADELE in Strassfurt aiming to achieve $70 \%$ overall storage efficiency. The Hydrostor project in Lake Ontario, Canada employs an alternative, novel, and rather elegant design with submerged air balloons acting as storage vessels for the compressed air, ${ }^{165}$ thus potentially expanding the range of applications of this technology which is currently limited by location and availability of high-quality natural storage caverns to large lakes and easily accessible offshore locations.

Batteries are the most promising medium for low to intermediate capacity buildings and district storage needs. ${ }^{166}$ Perhaps the most widely used batteries are of lead-acid type given their wide availability, established low-tech technology, and a very low cost of around $100 \$ / \mathrm{kW}$ h installed capacity. Newest generation "gel-type" and "flooded-type" lead acid batteries have significantly improved on both aspects but still are far from ideal for stationary high-volume storage given their need for regular maintenance (replenishing lost water) and poor service life (only a few hundred cycles). ${ }^{167}$ Nickel-cadmium batteries and the more advanced nickel metal hydride (NiMH) cells have significantly higher life span than lead acid batteries but are considerably more expensive. Modern cylindrical NiMH cells offer roughly twice the volumetric energy density (in the 250-300 W h/L range) compared to NiCd batteries. This highenergy density, combined with low maintenance, good storage efficiency, and long lifetime (3000 cycles at $100 \%$ depth of discharge), makes them ideal for stationary applications. The toptier class of batteries is based on the Lithium-ion technology. It offers superior gravimetric and volumetric storage densities as well as excellent cycle stability. Various technologies exist, but cells employing inorganic oxide type solid state cathode materials, e.g., lithium iron phosphate $\left(\mathrm{LiFePO}_{4}\right)$, lithium ion manganate $\left(\mathrm{LiMn}_{2} \mathrm{O}_{4}, \mathrm{Li}_{2} \mathrm{MnO}_{3}\right)$, and lithium nickel manganese/cobalt oxide $\left(\mathrm{LiNiMnCoO}_{2}\right)$, are generally more stable than, for example, lithium polymer (LiPo) cells and hence seem better suited for stationary storage. Just a few years ago, the cost of lithium ion batteries were still significantly higher at around $1000 \$ / \mathrm{kW} \mathrm{h}$ capacity, but rapid advances and commercialization of electric vehicles (EVs) have driven prices down to the $300 \$ / \mathrm{kW} \mathrm{h}$ range $^{168}$ and insider analysts even cite $190 \$ / \mathrm{kW} h$, which makes them competitive for stationary storage. A possible scenario pursued by Tesla Motors is the refurbishing of Li-ion cells from used EV battery packs for domestic storage needs, thus extending the life cycle of those batteries to be used in wallmounted modules for domestic electrical storage.

High-temperature batteries typically use alkali metal anodes in liquid form. Common systems are sodium sulfur (Na/S) and sodium/nickel chloride (ZEBRA battery) systems. Hightemperature batteries offer excellent efficiency (>85\%), lifetime (2500-5000 cycles at $80 \%$ depth of discharge), and relatively low-cost components. At the system level, however, thermal and safety management are issues which render this technology less competitive. Although in principle a highly attractive stationary battery storage concept, the market prospects of $\mathrm{Na} / \mathrm{S}$, $\mathrm{Li} / \mathrm{S}$, and Zebra batteries are being challenged by the rapid capacity increase and drop in prices of lithium ion cells. A more recent adaptation of the thermal battery concept typically used in military applications is the so-called liquid-metal battery developed by AMBRI, an MIT spinoff. The concept is based on liquid metal electrodes and a molten salt electrolyte and was developed for medium-scale stationary storage applications. ${ }^{169}$ Despite the somewhat lower energy density, the technology uses low-cost components and a design that can yield lifetimes $>10,000$ cycles, assuming that cell sealing and material durability issues can be solved.

The most recent addition to the battery family, redox flow batteries, are based on liquid anode and cathode materials which are converted in a dual flow cell type setup. ${ }^{170}$ Redox flow batteries offer not only relatively low energy densities but also the advantage of decoupled redox and conversion systems, thus also enabling long-term (seasonal) storage solutions. 
This decoupled design also results in outstanding cycling stability which makes it a promising solution for stationary applications.

Chemical electrical energy storage, for example, in the form of hydrogen or syngas (synthetic methane) is less relevant at the single building level but can add great long-term storage flexibility to energy district networks and is expected to find more widespread use in mobility applications. ${ }^{171}$

\section{Dynamic behaviour, building energy management and smart grids}

Efficient operation of modern buildings is a challenge, particularly when implementing renewable energy production. The problem of building energy management is clearly multidimensional. ${ }^{172}$ A summary of the use of a full set of metaheuristic optimization methods for finding the optimal operation of energy systems including electric and thermal storage as well as a heat source is given in Ikeda and Ooka. ${ }^{173}$ The occupants display a dynamic range of behaviors with strong temporal variations at diurnal, weekly, and seasonal length scales in terms of thermal comfort, light intensity, and air quality requirements. At the same time, buildings are only partially insulated from the weather outside. Furthermore, energy cost, supply, and demand are expected to fluctuate dramatically in a world of renewable energy. The goal is to find the right compromise between the conflicting demands of users' comfort, energy consumption, and cost and $\mathrm{CO}_{2}$ emissions. The management system then implements the selected strategy in terms of the input and storage of renewable energy (thermal and electrical), solar gains, controlled ventilation, and the operation of household appliances. Smart homes are equipped with sensors that not only feed into the building energy management system but also improve the safety of, e.g., elderly occupants. ${ }^{174}$ There is an extensive literature on optimization algorithms and strategies, such as whole building simulations, ${ }^{175}$ model predictive control, ${ }^{176}$ evolutionary programming ${ }^{177}$ and genetic algorithms, ${ }^{178}$ artificial neural networks, ${ }^{179}$ and particle swarm optimization. ${ }^{180}$ Taking into account the weather prediction and its associated uncertainties further increases the comfort and lowers energy consumption. ${ }^{181}$ Other building energy management systems include real-time variations in energy prices. ${ }^{182,183}$

As buildings become energy producers as well as consumers, integrating these decentralized energy systems at the neighborhood and at the district scale enables a further reduction in energy consumption and $\mathrm{CO}_{2}$ emissions. ${ }^{184}$ This integration requires the modification of district heating networks ${ }^{185}$ and smart grids that can deal with decentralized electricity production, consumption, and storage, including those associated with electric vehicles. ${ }^{186}$ There is a strong need for standardization to ensure the compatibility of the various technical installations at both the building and the district level, and this is an area where policy can make a difference.

\section{Energy demand of buildings}

To understand the energy demand of buildings and how it can be potentially changed, it is important to consider three different aspects, namely, (i) building energy efficiency, (ii) rebound effects, and (iii) occupant behavior, which we will do in the following.

\section{Building energy efficiency}

By using renewable energy sources, such as heat pumps, photovoltaics, or solar thermal energy, even a building with a suboptimal building envelope can be run sustainably. However, given the control function of the building envelope and the possibility to incorporate passive heating or cooling elements, a well-designed envelope can greatly increase a building's energy efficiency and its indoor thermal comfort. Pacheco and co-workers ${ }^{187}$ evaluated the best design options for a number of building parameters, including orientation, shape, envelope system, passive heating and cooling mechanisms, shading, and glazing, to optimize the energy consumption. Passive design strategies were also studied in Ref. 188 for plus energy houses. Furthermore, the design of the building envelope can be optimized with respect to its embodied energy, for example, with respect to the ideal insulation thickness as discussed by Wolgemuth et al. ${ }^{44}$ Considering primary energy, global warming potential, and environmental impact points, the optimal insulation thickness is higher when outdoor temperatures are lower, indoor temperatures higher, the building smaller, and the environmental impact of the heat generation higher. For Switzerland, $20 \mathrm{~cm}$ of conventional insulation with a $U$-value of $\sim 0.15 \mathrm{~W} /\left(\mathrm{m}^{2} \mathrm{~K}\right)$ is considered optimal for most cases. Copiello ${ }^{189}$ shows that the embodied energy of building materials can be predicted by their production costs and shows how the embodied energy increases from low-energy buildings, to passive houses and self sufficient buildings, while the operating energy goes to zero at the same time. The combined energy optimum is reached for passive houses. Besides a well-designed building envelope, the proper operation of all energy relevant building services is a necessary condition for a low-energy building (see Dynamic Behavior, Building Energy Management and Smart Grids section above). Regarding this aspect, modern machine learning algorithms have found applications in building performance optimization problems.

However, high-energy saving potential lies not in the optimization of building elements and its operation alone but also in the target settings for thermal comfort. As mentioned in the Thermal Comfort section, heat balance models of thermal comfort might be too conservative for the definition of the desired parameter range of thermal comfort. That implies that the heating or cooling devices are used more than actually necessary to achieve thermal comfort of the occupants.

\section{The rebound effect, the energy savings deficit \& the energy performance gap}

Energy efficiency in buildings is not sufficient, though, to reach goals on energy use and climate change containment. Undoubtedly, buildings have become much more energy efficient in the last decades, but this development has been accompanied by the so-called "rebound effect" on different levels. An increase in energy efficiency of a product or service can lead to a 
lower price and, with that, to an increased demand for it. The partial or complete offset of the initial energy efficiency increase by this ensuing demand increase is called a rebound effect. When the efficiency is more than offset, the effect is sometimes called the "Jevons" paradox. Greening et al. ${ }^{190}$ describe the rebound effect for different energy-related products. For the case of space-heating, the authors find it to be around 10-30\%, i.e., any technological improvement will only be $70-90 \%$ effective in reducing energy consumption. Similar results are presented in a review by Sorrell and co-workers. ${ }^{191}$ Regarding energy consumption in buildings, the increased consumption described by the rebound effect stem from an increase in thermal comfort and air quality, e.g., by higher inside temperatures in the winter, longer heating periods during the year, and higher ventilation rates, as well as from an increase in the living area in many countries. For example, a significant increase in living space per person has been observed in Switzerland, with an increase from 30 to $41 \mathrm{~m}^{2}$ /person from 1970 to 2013 in the city of Zürich ${ }^{192}$ or in Germany, with an overall $13 \%$ increase between 1996 and 2006. ${ }^{193}$ Hence, the improvement of building thermal efficiency, i.e., by lower $U$-values, heat pumps, solar thermal collectors, etc., has been partially compensated by warmer and bigger flats and offices.

There are two more similar effects, described by Galvin, ${ }^{194}$ that are sometimes confused with the rebound effect but which have different mechanisms. The first is the "energy savings deficit", defined as the shortfall of energy savings as a proportion of expected energy savings of a building retrofit. Earlier, SunikkaBlank and Galvin call it the "prebound effect". Examining existing data of 3400 homes in Germany, the authors found that, prior to the retrofit, the energy consumption was on an average $30 \%$ less than what was calculated. Hence, the saving potential of a retrofit measure was overestimated for these buildings. The second effect related to the rebound effect is the "energy performance gap". This denotes the ratio between the overconsumption of energy and the design consumption of a building, i.e., it shows a discrepancy between planned and real energy consumption.

\section{User behavior}

The existence of these two last effects, the energy savings deficit and the energy performance gap, points toward the last of the three aspects influencing building energy demand, namely user behavior. User behavior can radically alter the energy performance of a given building. This is shown, for example, in a California building and monitoring project, where a new settlement of near-zero-energy homes was built besides a conventional settlement. The electricity bills of the occupants of the two different settlements were compared. The evaluation showed that while the mean energy use of the near-zero-energy inhabitants was considerably lower than their neighbors' in the conventional homes, the distribution of energy use of both groups was fairly similar: both had inhabitants that used very little energy (or sometimes even had a surplus in case of the near-zero-energy homes) and others that had bills multiple times higher. ${ }^{195}$ This shows that purely architectural measures are necessary but not sufficient conditions for low energy use in buildings. Kathryn Janda gives an overview on the pivotal role of occupants in building energy use. ${ }^{196}$ Unfortunately, this role is often neglected and is still poorly understood. According to Janda, energy intense user behavior can be explained (i) by a lack of information about how to save energy-this is the so-called information deficit model-or (ii) by habits, practices, and norms. Focusing on the first explanation, she calls for a better education of building users. One measure can be feedback: direct user feedback, e.g., through real-time consumption monitors, can bring improvements of up to $15 \%$, with indirect feedback, e.g., bills, being less influential with savings of up to $10 \%$. The impact of feedback is limited, though, as many usersoutside the group of building professionals-seem to not have sufficient knowledge on how to improve energy use. Hence, Janda suggests that either the existing group of building professionals, like architects and planners, or a new professional group should take up the responsibility for public education on "building literacy", i.e., how buildings can be operated with low energy use. A complementary approach is presented by Stevenson and Leaman who propose to more thoroughly take into account user feedback for the improvement of housing from an energy perspective. ${ }^{197}$ In either case, it is clear that the problem of high energy use and carbon dioxide emissions cannot be solved on a technological level alone but that a strong focus on building users is a complimentary necessity.

\section{Building retrofit}

As building codes become more stringent and new buildings more energy efficient, retrofitting the existing building stock has gained more prominence for the reduction of overall energy consumption. For example, in the canton of Zürich, Switzerland, in 2013 , more than $70 \%$ of the existing building stock had a total yearly energy consumption of more than $100 \mathrm{~kW} \mathrm{~h} / \mathrm{m}^{2}$ and was built before 1990, whereas many new buildings use less than $50 \mathrm{~kW} \mathrm{~h} / \mathrm{m}^{2} .198$ That means that further improvements of new buildings only have a marginal effect on the energy consumption of the entire building stock. Taking into account the energy savings deficit (see above), the energy savings that can be realized by retrofitting these older buildings will most likely be smaller than expected, as the actual energy use of old buildings tends to be less than the calculated values. Nevertheless, it is crucial to address the issue of old, poorly insulated buildings with outdated building technology to reduce the energy consumption of the building stock as a whole.

An overview on building retrofitting is given by Ma and co-workers. ${ }^{199}$ The authors note the very low renovation rate as well as the strong potential to increase the environmental performance of existing buildings. They illustrate the different phases of a retrofit with the concomitant retrofit activities and describe how the most suitable options for a retrofit can be selected. For that, it is crucial to take into account a retrofit of the whole building, i.e., for both the building technology and the thermal envelope. Kumbaroğlu and Madlener used Monte Carlo simulations to find the economically optimal set of retrofit 
measures, maximizing the net present value of the building. ${ }^{200}$ They reported that the economic appropriateness of retrofit measures strongly depend on energy prices, indicating that these might be the most important influencing factor of renovation rates. The authors also state that volatile energy prices make postponing the retrofit measure the more profitable option. Taking into account three target parameters, namely energy consumption, retrofit cost, and thermal discomfort hours, Asadi et al. ${ }^{201}$ showed that genetic algorithms combined with artificial neural networks solve the optimization problem much faster than conventional approaches. The optimization results can be used to evaluate the impact of individual retrofit measures and to facilitate decision making in a retrofit project.

Even though the optimal retrofit solution for a given building can be well understood in terms of technology, barriers to the successful planning and execution of an energy retrofit exist on several levels as described by Girod and co-workers ${ }^{202}$ : (i) structural (institutional or market related), (ii) behavioral (risk, availability of information, habits), and (iii) availability (capital, products, proper installation and use of the technology). The authors identified profitability and uncertainty with respect to costs and savings, access to capital, lack of information as well as correct installation as the most important barriers. A survey of more than 400 house owners ${ }^{203}$ finds access to capital, profitability, and furthermore a favorable opportunity (such as the need for replacement of a heating system) as requirements for a retrofit. This shows the importance not only to consider the technical but also the financial, behavioral, and political context of building retrofits to increase retrofit rates.

\section{Conclusion}

Various aspects of the science and technology of reducing energy demands of buildings are now well understood, and new materials and solutions are continuously developed for the building envelope and systems: airtight envelopes, superinsulation materials, triple and vacuum insulation glazing with switchable $g$-values, low-cost solar cells and modules, building integrated photovoltaics, heat pumps, heat and electrical storage, building energy management systems, and smart grids. Equally important is the continuous reduction in cost for these energy systems, which is a driver of intense R\&D. In addition to technology, user behavior affects the energy performance, sometimes to an even larger extent than the technology, and research is ongoing on how to modify this behavior. In fact, a more detailed knowledge about user behavior patterns may guide future developments on the materials and technology side. Variations in climate, economic power, building traditions and, perhaps most importantly, public perception and attitude toward climate change, have resulted in vastly different adoption rates of energy-efficient materials and technologies for different parts of our planet. Thanks to a coherent energy policy, the enforcement of strict building codes and the adoption of new materials and technologies for energy savings (building envelope), energy generation (renewables), and energy storage, the energy consumption and greenhouse gas emissions per square meter of new buildings have been reduced dramatically in many areas of Europe during the last few decades, although these gains are offset by the per capita increases in the living area. As a result, the focus within Europe is shifting toward the retrofit of the existing building stock with its poorly insulated, nonairtight building envelopes and outdated building technology. For new construction, a decent energy performance is required to obtain a building permit and research efforts now also target thermal comfort, IAQ, and user behavior, in addition to energy efficiency and energy technology alone. In contrast, different perceptions of the risks and consequences of climate change in the United States have resulted in a less coherent energy policy and less stringent building codes. As a result, the adoption of energy saving materials and technologies is lagging behind Europe and this inertia is magnified globally because of the exemplary role of the United States, particularly with second and third world countries. The growth of the middle class in the countries like China, Brazil, and India, and their increasing demand for thermal comfort, will precipitate a strong increase in cooling energy demands, unless efficient and sustainable solutions can be implemented readily and quickly.

\section{REFERENCES:}

1. Parmesan C. and Yohe G.: A globally coherent fingerprint of climate change impacts across natural systems. Nature 421(6918), 37-42 (2003).

2. Christianson G.E.: Greenhouse; the 200-Year Story of Global Warming (Walker \& Company, New York, NY, 1999).

3. Easterling D.R., Meehl G.A., Parmesan C., Changnon S.A., Karl T.R., and Mearns L.O.: Climate extremes: Observations, modeling, and impacts. Science 289(5487), 2068-2074 (2000).

4. Menzel A., Sparks T.H., Estrella N., Koch E., Aasa A., Ahas R., Alm-Kübler K. Bissolli P., Braslavská O., and Briede A.: European phenological response to climate change matches the warming pattern. Global Change Biol. 12(10), 1969-1976 (2006).

5. McCright A.M. and Dunlap R.E.: Defeating Kyoto: The conservative movement's impact on US climate change policy. Soc. Probl. 50(3), 348-373 (2003).

6. Coumou D. and Rahmstorf S.: A decade of weather extremes. Nat. Clim. Change 2(7), 491-496 (2012).

7. Leiserowitz A.A.: American risk perceptions: Is climate change dangerous? Risk Anal. 25(6), 1433-1442 (2005).

8. Lorenzoni I. and Pidgeon N.F.: Public views on climate change: European and USA perspectives. Clim. Change 77(1-2), 73-95 (2006).

9. Haines A., Smith K.R., Anderson D., Epstein P.R., McMichael A.J., Roberts I., Wilkinson P., Woodcock J., and Woods J.: Policies for accelerating access to clean energy, improving health, advancing development, and mitigating climate change. Lancet 370(9594), 1264-1281 (2007).

10. Biesbroek G.R., Swart R.J., Carter T.R., Cowan C., Henrichs T., Mela H., Morecroft M.D., and Rey D.: Europe adapts to climate change: Comparing national adaptation strategies. Global Environ. Change 20(3), 440-450 (2010).

11. Tompkins E.L., Adger W.N., Boyd E., Nicholson-Cole S., Weatherhead K., and Arnell N.: Observed adaptation to climate change: UK evidence of transition to a well-adapting society. Global Environ. Change 20(4), 627-635 (2010).

12. Meinshausen M., Meinshausen N., Hare W., Raper S.C., Frieler K., Knutti R., Frame D.J., and Allen M.R.: Greenhouse-gas emission targets for limiting global warming to $2{ }^{\circ} \mathrm{C}$. Nature 458(7242), 1158-1162 (2009).

13. Enerdata Statistical Yearbook (2016). Available at: https://yearbook. enerdata.net/ (accessed June 21, 2017).

14. He Y., Xu Y., Pang Y., Tian H., and Wu R.: A regulatory policy to promote renewable energy consumption in China: Review and future evolutionary path. Renew. Energy 89, 695-705 (2016). 
15. Jacobsson S. and Lauber V.: The politics and policy of energy system transformation-Explaining the German diffusion of renewable energy technology. Energy Policy 34(3), 256-276 (2006).

16. Chowdhury S., Sumita U., Islam A., and Bedja I.: Importance of policy for energy system transformation: Diffusion of PV technology in Japan and Germany. Energy Policy 68, 285-293 (2014).

17. Lauber V. and Jacobsson S.: The politics and economics of constructing, contesting and restricting socio-political space for renewables-The German Renewable Energy Act. Environ. Innov. Soc. Transit. 18, 147-163 (2016).

18. Ürge-Vorsatz D., Cabeza L.F., Serrano S., Barreneche C., and Petrichenko K.: Heating and cooling energy trends and drivers in buildings. Renewable Sustainable Energy Rev. 41, 85-98 (2015).

19. Roberts S.: Effects of climate change on the built environment. Energy Policy 36(12), 4552-4557 (2008).

20. Pongiglione M. and Calderini C.: Sustainable structural design: Comprehensive literature review. J. Struct. Eng. 142(12), 4016139 (2016).

21. LaFrance M.: Technology Roadmap: Energy Efficient Building Envelopes (International Energy Agency, Paris, 2013).

22. Mirasgedis S., Georgopoulou E., Sarafidis Y., Balaras C., Gaglia A., and Lalas D.: $\mathrm{CO}_{2}$ emission reduction policies in the Greek residential sector: A methodological framework for their economic evaluation. Energy Convers. Manage. 45(4), 537-557 (2004).

23. Martinsen D., Markewitz P., and Vögele P.M.S.: Roads to Carbon Reduction in Germany (International Workshop by Energy Modelling Forum, IEA and IIASA, Laxenburg, Austria, 2003).

24. Lechtenböhmer S., Grimm V., Mitze D., Thomas S., and Wissner M.: Target 2020: Policies and Measures to Reduce Greenhouse Gas Emissions in the EU (Wuppertal Institut für Klima, Umwelt, Energie, Wuppertal, Germany, 2005).

25. Enviros Consulting Ltd.: Review and Development of Carbon Abatement Curves for Available Technologies as Part of the Energy Efficiency Innovation Review (Enviros, Prague, 2005).

26. Jaccard M.K.: Construction and Analysis of Sectoral, Regional and National Cost Curves of GHG Abatement of Canada (Natural Resources Canada, Vancouver, 2002).

27. Koomey J.G., Webber C.A., Atkinson C.S., and Nicholls A.: Addressing energy-related challenges for the US buildings sector: Results from the clean energy futures study. Energy Policy 29(14), 1209-1221 (2001).

28. National Institute for Environmental Studies Japan: GHG Emissions and Climate Change (NIES, Tsukuba, 2004).

29. ERI National Development and Reform Commission: China National Energy Strategy and Policy to 2020 (ERI, Beijing, 2004).

30. Murakami S., Levine M.D., Yoshino H., Inoue T., Ikaga T., Shimoda Y., Miura S., Sera T., Nishio M., and Sakamoto Y.: Energy consumption and mitigation technologies of the building sector in Japan. In $6 t h$ International Conference on Indoor Air Quality, Ventilation \& Energy Conservation in Buildings IAQVEC (Tohoku University Press, Sendai, Japan, 2007).

31. Izrael Y.A., Avdjuhsin S.I., Nazarov I.M., Kokorin A.O., Nakhutin A.I., and Yakovlev A.F.: Russian Federation Climate Change Country Study, Climate Change Action Plan (Russian Federal Service for Hydrometeorology and Environmental Monitoring, Moscow, 1999).

32. Australian Greenhouse Office: National appliances and equipment programs: When you keep measuring it, you know even more about it-Projected impacts 2005-2020 (2005). Available at: www.energyrating. gov.au/ (accessed June 21, 2017).

33. Ürge-Vorsatz D. and Novikova A.: Potentials and costs of carbon dioxide mitigation in the world's buildings. Energy Policy 36(2), 642-661 (2008).

34. Ionescu C., Baracu T., Vlad G-E., Necula H., and Badea A.: The historical evolution of the energy efficient buildings. Renewable Sustainable Energy Rev. 49, 243-253 (2015).

35. Bozsaky D.: The historical development of thermal insulation materials. Period. Polytech. 41(2), 49-56 (2010).

36. A'zami A.: Badgir in traditional Iranian architecture. International Conference "Passive and Low Energy Colling for the Built Environment (Santorini, Greece, 2005).
37. Stetson T.D.: Improvement in window-glass (1865). Available at: http://google.com/patents/US49167 (accessed November 21, 2016).

38. 80 years: The House of Tomorrow: Solar house history. Available at: http:// solarhousehistory.com/blog/2013/4/21/80-years (accessed November 21, 2016).

39. SOLAR 7: History • Solar1. Available at: http://web.mit.edu/ solardecathlon/solar1.html (accessed November 21, 2016).

40. Kusuda T.: Early history and future prospects of building system simulation. In Proceedings of Building Simulation, Vol. 99 (1999); pp. 3-15.

41. Van Hoof J.: Forty years of Fanger's model of thermal comfort: Comfort for all? Indoor Air 18(3), 182-201 (2008).

42. Feist W. and Schnieders J.: Energy efficiency-A key to sustainable housing. Eur. Phys. J.: Spec. Top. 176(1), 141-153 (2009).

43. Voss K., Goetzberger A., Bopp G., Häberle A., Heinzel A., and Lehmberg H.: The self-sufficient solar house in Freiburg-Results of 3 years of operation. Sol. Energy 58(1), 17-23 (1996).

44. Wohlgemuth D., von Gunten D., Manz H., Zeyer C., and Althaus H-J.: Ökologisch optimale Dämmdicken bei Wohngebäuden. Bauphysik 37(5), 277-283 (2015).

45. Kaynakli O.: A review of the economical and optimum thermal insulation thickness for building applications. Renewable Sustainable Energy Rev. 16(1), 415-425 (2012).

46. Al-Homoud M.S.: The effectiveness of thermal insulation in different types of buildings in hot climates. J. Therm. Envelope Build. Sci. 27(3), 235-247 (2004).

47. Sadineni S.B., Madala S., and Boehm R.F.: Passive building energy savings: A review of building envelope components. Renewable Sustainable Energy Rev. 15(8), 3617-3631 (2011).

48. Fennell H.C. and Haehnel J.: Setting airtightness standards. ASHRAE J. 47(9), 26-31 (2005).

49. Dodoo A., Gustavsson L., and Sathre R.: Primary energy implications of ventilation heat recovery in residential buildings. Energy Build. 43(7), 1566-1572 (2011).

50. Jelle B.P.: Traditional, state-of-the-art and future thermal building insulation materials and solutions-Properties, requirements and possibilities. Energy Build. 43(10), 2549-2563 (2011).

51. Stec A.A. and Hull T.R.: Assessment of the fire toxicity of building insulation materials. Energy Build. 43(2-3), 498-506 (2011).

52. Tyagi V.V. and Buddhi D.: PCM thermal storage in buildings: A state of art. Renewable Sustainable Energy Rev. 11(6), 1146-1166 (2007).

53. Zinzi M. and Agnoli S.: Cool and green roofs. An energy and comfort comparison between passive cooling and mitigation urban heat island techniques for residential buildings in the Mediterranean region. Energy Build. 55, 66-76 (2012).

54. Liu K. and Baskaran B.: Thermal performance of green roofs through field evaluation. In Proceedings for the First North American Green Roof Infrastructure Conference (Green Roofs for Healthy Cities, Ontario, Canada, 2003); pp. 1-10.

55. Santamouris M.: Cooling the cities-A review of reflective and green roof mitigation technologies to fight heat island and improve comfort in urban environments. Sol. Energy 103, 682-703 (2014).

56. Fioretti R., Palla A., Lanza L.G., and Principi P.: Green roof energy and water related performance in the Mediterranean climate. Build. Environ. 45(8), 1890-1904 (2010).

57. Castleton H.F., Stovin V., Beck S.B.M., and Davison J.B.: Green roofs; building energy savings and the potential for retrofit. Energy Build. 42(10), 1582-1591 (2010).

58. Sheweka S.M. and Mohamed N.M.: Green facades as a new sustainable approach towards climate change. Energy Procedia 18, 507-520 (2012).

59. Pérez G., Rincón L., Vila A., González J.M., and Cabeza L.F.: Behaviour of green facades in Mediterranean continental climate. Energy Convers. Manage. 52(4), 1861-1867 (2011).

60. Djongyang N., Tchinda R., and Njomo D.: Thermal comfort: A review paper. Renewable Sustainable Energy Rev. 14(9), 2626-2640 (2010).

61. Yang L., Yan H., and Lam J.C.: Thermal comfort and building energy consumption implications-A review. Appl. Energy 115, 164-173 (2014). 
62. Kwong Q.J., Adam N.M., and Sahari B.B.: Thermal comfort assessment and potential for energy efficiency enhancement in modern tropical buildings: A review. Energy Build. 68(Part A), 547-557 (2014).

63. Cheng Y., Niu J., and Gao N.: Thermal comfort models: A review and numerical investigation. Build. Environ. 47, 13-22 (2012).

64. Holopainen R., Tuomaala P., Hernandez P., Häkkinen T., Piira K., and Piippo J.: Comfort assessment in the context of sustainable buildings: Comparison of simplified and detailed human thermal sensation methods. Build. Environ. 71, 60-70 (2014).

65. Lim S.S., Vos T., Flaxman A.D., Danaei G., Shibuya K., Adair-Rohani H., Amann M., Anderson H.R., Andrews K.G., Aryee M., Atkinson C., Bacchus L.J., Bahalim A.N., Balakrishnan K., Balmes J., Barker-Collo S., Baxter A., Bell M.L., Blore J.D., Blyth F., Bonner C., Borges G., Bourne R., Boussinesq M., Brauer M., Brooks P., Bruce N.G., Brunekreef B., Bryan-Hancock C., Bucello C., Buchbinder R., Bull F., Burnett R.T., Byers T.E., Calabria B., Carapetis J., Carnahan E., Chafe Z., Charlson F., Chen H., Chen J.S., Cheng A.T-A., Child J.C., Cohen A., Colson K.E., Cowie B.C., Darby S., Darling S., Davis A., Degenhardt L., Dentener F., Jarlais Des, D.C., Devries K., Dherani M., Ding E.L., Dorsey E.R., Driscoll T., Edmond K., Ali S.E., Engell R.E., Erwin P.J., Fahimi S., Falder G., Farzadfar F., Ferrari A., Finucane M.M., Flaxman S., Fowkes F.G.R., Freedman G., Freeman M.K., Gakidou E., Ghosh S., Giovannucci E., Gmel G., Graham K., Grainger R., Grant B., Gunnell D., Gutierrez H.R., Hall W., Hoek H.W., Hogan A., Hosgood H.D., Hoy D., Hu H., Hubbell B.J., Hutchings S.J., Ibeanusi S.E., Jacklyn G.L., Jasrasaria R., Jonas J.B., Kan H., Kanis J.A., Kassebaum N., Kawakami N., Khang Y-H., Khatibzadeh S., Khoo J-P., Kok C., Laden F., Lalloo R., Lan Q., Lathlean T., Leasher J.L., Leigh J., Li Y., Lin J.K., Lipshultz S.E., London S., Lozano R., Lu Y., Mak J., Malekzadeh R., Mallinger L., Marcenes W., March L., Marks R., Martin R., McGale P., McGrath J., Mehta S., Mensah G.A., Merriman T.R., Micha R., Michaud C., Mishra V., Mohd Hanafiah K., Mokdad A.A., Morawska L., Mozaffarian D., Murphy T., Naghavi M., Neal B., Nelson P.K., Nolla J.M., Norman R., Olives C., Omer S.B., Orchard J., Osborne R., Ostro B., Page A., Pandey K.D., Parry C.D.H., Passmore E., Patra J., Pearce N., Pelizzari P.M., Petzold M., Phillips M.R., Pope D., Pope C.A., Powles J., Rao M., Razavi H., Rehfuess E.A., Rehm J.T., Ritz B., Rivara F.P., Roberts T., Robinson C., Rodriguez-Portales J.A., Romieu I., Room R., Rosenfeld L.C., Roy A., Rushton L., Salomon J.A., Sampson U., Sanchez-Riera L., Sanman E., Sapkota A., Seedat S., Shi P., Shield K., Shivakoti R., Singh G.M., Sleet D.A., Smith E., Smith K.R., Stapelberg N.J.C., Steenland K., Stöckl H., Stovner L.J., Straif K., Straney L., Thurston G.D., Tran J.H., Van Dingenen R., van Donkelaar A., Veerman J.L., Vijayakumar L., Weintraub R., Weissman M.M., White R.A., Whiteford H., Wiersma S.T., Wilkinson J.D., Williams H.C., Williams W., Wilson N., Woolf A.D., Yip P., Zielinski J.M., Lopez A.D., Murray C.J.L., Ezzati M., AlMazroa M.A., and Memish Z.A.: A comparative risk assessment of burden of disease and injury attributable to 67 risk factors and risk factor clusters in 21 regions, 1990-2010: A systematic analysis for the global burden of disease study 2010. Lancet 380(9859), 2224-2260 (2012).

66. Sundell J.: On the history of indoor air quality and health. Indoor Air 14(Suppl. 7), 51-58 (2004).

67. Runeson-Broberg R. and Norbäck D.: Sick building syndrome (SBS) and sick house syndrome (SHS) in relation to psychosocial stress at work in the Swedish workforce. Int. Arch. Occup. Environ. Health 86(8), 915-922 (2013).

68. Peng R.D., Butz A.M., Hackstadt A.J., Williams D.L., Diette G.B., Breysse P.N., and Matsui E.C.: Estimating the health benefit of reducing indoor air pollution in a randomized environmental intervention. J. R. Statist. Soc. A 178(2), 425-443 (2015).

69. Sundell J., Levin H., Nazaroff W.W., Cain W.S., Fisk W.J., Grimsrud D.T., Gyntelberg F., Li Y., Persily A.K., Pickering A.C., Samet J.M., Spengler J.D., Taylor S.T., and Weschler C.J.: Ventilation rates and health: Multidisciplinary review of the scientific literature. Indoor Air 21(3), 191-204 (2011).

70. Bornehag C.G., Blomquist G., Gyntelberg F., Järvholm B., Malmberg P., Nordvall L., Nielsen A., Pershagen G., and Sundell J.: Dampness in buildings and health. Nordic interdisciplinary review of the scientific evidence on associations between exposure to "dampness" in buildings and health effects (NORDDAMP). Indoor Air 11(2), 72-86 (2001).
71. Wargocki P., Sundell J., Bischof W., Brundrett G., Fanger P.O., Gyntelberg F., Hanssen S.O., Harrison P., Pickering A., Seppänen O., and Wouters P.: Ventilation and health in non-industrial indoor environments: Report from a European Multidisciplinary Scientific Consensus Meeting (EUROVEN). Indoor Air 12(2), 113-128 (2002).

72. Maddalena R., Mendell M.J., Eliseeva K., Chan W.R., Sullivan D.P., Russell M., Satish U., and Fisk W.J.: Effects of ventilation rate per person and per floor area on perceived air quality, sick building syndrome symptoms, and decision-making. Indoor Air 25(4), 362-370 (2015).

73. Park J.S. and Yoon C.H.: The effects of outdoor air supply rate on work performance during 8-h work period. Indoor Air 21(4), 284-290 (2011).

74. Seppänen O., Fisk W.J., and Lei Q.H.: Ventilation and performance in office work. Indoor Air 16(1), 28-36 (2006).

75. Haverinen-Shaughnessy U., Moschandreas D.J., and Shaughnessy R.J.: Association between substandard classroom ventilation rates and students' academic achievement. Indoor Air 21(2), 121-131 (2011).

76. Lu T., Lü X., and Viljanen M.: A novel and dynamic demand-controlled ventilation strategy for $\mathrm{CO}_{2}$ control and energy saving in buildings. Energy Build. 43(9), 2499-2508 (2011).

77. Koebel M., Rigacci A., and Achard P.: Aerogel-based thermal superinsulation: An overview. J. Sol-Gel Sci. Technol. 63(3), 315-339 (2012).

78. Freedonia Market Study \#2434: World Insulation (Freedonia, Cleveland, 2009).

79. Hale R.C., La Guardia M.J., Harvey E., and Mainor T.M.: Potential role of fire retardant-treated polyurethane foam as a source of brominated diphenyl ethers to the US environment. Chemosphere 46(5), 729-735 (2002).

80. Blanco F., García P., Mateos P., and Ayala J.: Characteristics and properties of lightweight concrete manufactured with cenospheres. Cem. Concr. Res. 30(11), 1715-1722 (2000).

81. Baetens R., Jelle B.P., Gustavsen A., and Grynning S.: Gas-filled panels for building applications: A state-of-the-art review. Energy Build. 42(11), 1969-1975 (2010).

82. Lux Research Market Study \#17198: Mapping Advanced Insulation Materials to Markets: Assessing Aerogel, Vacuum Insulation Panel, and Phase-Change Material Opportunities Beyond Building Applications (2015).

83. Kwon J-S., Jang C.H., Jung H., and Song T-H.: Effective thermal conductivity of various filling materials for vacuum insulation panels. Int. J. Heat Mass Transfer 52(23), 5525-5532 (2009).

84. Simmler H. and Brunner S.: Vacuum insulation panels for building application: Basic properties, aging mechanisms and service life. Energy Build. 37(11), 1122-1131 (2005).

85. Stahl T., Brunner S., Zimmermann M., and Koebel M.: Thermally insulating aerogel based rendering materials. Patent WO 2014090790 A1, 2014.

86. Fickler S., Milow B., Ratke L., Schnellenbach-Held M., and Welsch T.: Development of high performance aerogel concrete. Energy Procedia 78, 406-411 (2015).

87. Rezaei S.D., Shannigrahi S., and Ramakrishna S.: A review of conventional, advanced, and smart glazing technologies and materials for improving indoor environment. Sol. Energy Mater. Sol. Cells 159, 26-51 (2017).

88. Manz H.: On minimizing heat transport in architectural glazing. Renew. Energy 33(1), 119-128 (2008).

89. Jelle B.P., Kalnæs S.E., and Gao T.: Low-emissivity materials for building applications: A state-of-the-art review and future research perspectives. Energy Build. 96, 329-356 (2015).

90. Van Den Bergh S., Hart R., Jelle B.P., and Gustavsen A.: Window spacers and edge seals in insulating glass units: A state-of-the-art review and future perspectives. Energy Build. 58, 263-280 (2013).

91. Jelle B.P., Hynd A., Gustavsen A., Arasteh D., Goudey H., and Hart R.: Fenestration of today and tomorrow: A state-of-the-art review and future research opportunities. Sol. Energy Mater. Sol. Cells 96, 1-28 (2012).

92. Gustavsen A., Grynning S., Arasteh D., Jelle B.P., and Goudey H.: Key elements of and material performance targets for highly insulating window frames. Energy Build. 43(10), 2583-2594 (2011).

93. Thalfeldt M., Pikas E., Kurnitski J., and Voll H.: Facade design principles for nearly zero energy buildings in a cold climate. Energy Build. 67, 309-321 (2013). 
94. Hood T.G., Vincent S.M., and Booth R.: High performance, thermally insulating multipane glazing structure. U.S. Patent No. 5156894 A, 1992.

95. Collins R.E. and Simko T.M.: Current status of the science and technology of vacuum glazing. Sol. Energy 62(3), 189-213 (1998).

96. Simko T. and Collins R.E.: Vacuum glazing: Development, design challenges and commercialisation. Aust. J. Mech. Eng. 12(3), 305-316 (2014).

97. Cuce E. and Cuce P.M.: Vacuum glazing for highly insulating windows: Recent developments and future prospects. Renewable Sustainable Energy Rev. 54, 1345-1357 (2016).

98. Buratti C. and Moretti E.: Experimental performance evaluation of aerogel glazing systems. In Energy Solutions for a Sustainable World-Proceedings of the Third International Conference on Applied Energy, May 16-18, 2011-Perugia, Italy, Vol. 97 (2012); pp. 430-437.

99. Schultz J.M., Jensen K.I., and Kristiansen F.H.: Super insulating aerogel glazing. Sol. Energy Mater. Sol. Cells 89(2-3), 275-285 (2005).

100. Jensen K.I., Schultz J.M., and Kristiansen F.H.: Development of windows based on highly insulating aerogel glazings. In Aerogels 7. Proceedings of the 7th International Symposium on Aerogels 7th International Symposium on Aerogels, Vol. 350 (Alexandria, VA, 2004); pp. 351-357.

101. Reim M., Körner W., Manara J., Korder S., Arduini-Schuster M., Ebert H-P., and Fricke J.: Silica aerogel granulate material for thermal insulation and daylighting. CISBAT'O3: Innovation in Building Envelopes and Environmental Systems 79(2), 131-139 (2005).

102. Raut H.K., Ganesh V.A., Nair A.S., and Ramakrishna S.: Anti-reflective coatings: A critical, in-depth review. Energy Environ. Sci. 4(10), 3779-3804 (2011).

103. Fernandes L.L., Lee E.S., McNeil A., Jonsson J.C., Nouidui T., Pang X., and Hoffmann S.: Angular selective window systems: Assessment of technical potential for energy savings. Energy Build. 90, 188-206 (2015).

104. Gong J., Kostro A., Motamed A., and Schueler A.: Potential advantages of a multifunctional complex fenestration system with embedded micro-mirrors in daylighting. Sol. Energy 139, 412-425 (2016).

105. Georg A., Georg A., Graf W., and Wittwer V.: Switchable windows with tungsten oxide. Vacuum 82(7), 730-735 (2008).

106. Granqvist C.G.: Electrochromic tungsten oxide films: Review of progress 1993-1998. Sol. Energy Mater. Sol. Cells 60(3), 201-262 (2000).

107. Wittwer V., Datz M., Ell J., Georg A., Graf W., and Walze G.: Gasochromic windows. Sol. Energy Mater. Sol. Cells 84(1), 305-314 (2004).

108. Hauch A., Georg A., Baumgärtner S., Krašovec U.O., and Orel B.: New photoelectrochromic device. Electrochim. Acta 46(13), 2131-2136 (2001).

109. Parkin I.P. and Manning T.D.: Intelligent thermochromic windows. J. Chem. Educ. 83(3), 393 (2006).

110. Livage J. and Ganguli D.: Sol-gel electrochromic coatings and devices: A review. Sol. Energy Mater. Sol. Cells 68(3), 365-381 (2001).

111. Lee S., Deshpande R., Parilla P.A., Jones K.M., To B., Mahan A.H., and Dillon A.C.: Crystalline $\mathrm{WO}_{3}$ nanoparticles for highly improved electrochromic applications. Adv. Mater. 18(6), 763-766 (2006).

112. Scherer M.R., Li L., Cunha P., Scherman O.A., and Steiner U.: Enhanced electrochromism in gyroid-structured vanadium pentoxide. Adv. Mater. 24(9), 1217-1221 (2012).

113. Sialvi M.Z., Mortimer R.J., Wilcox G.D., Teridi A.M., Varley T.S., Wijayantha K.U., and Kirk C.A.: Electrochromic and colorimetric properties of nickel(II) oxide thin films prepared by aerosol-assisted chemical vapor deposition. ACS Appl. Mater. Interfaces 5(12), 5675-5682 (2013).

114. Thakur V.K., Ding G., Ma J., Lee P.S., and Lu X.: Hybrid materials and polymer electrolytes for electrochromic device applications. Adv. Mater. 24(30), 4071-4096 (2012).

115. Marcilla R., Alcaide F., Sardon H., Pomposo J.A., Pozo-Gonzalo C., and Mecerreyes D.: Tailor-made polymer electrolytes based upon ionic liquids and their application in all-plastic electrochromic devices. Electrochem. Commun. 8(3), 482-488 (2006).

116. Runnerstrom E.L., Llordés A., Lounis S.D., and Milliron D.J.: Nanostructured electrochromic smart windows: Traditional materials and NIR-selective plasmonic nanocrystals. Chem. Commun. 50(73), 10555-10572 (2014).
117. Stopper J., Boeing F., and Gstoehl D.: Fluid Glass Façade Elements: Energy Balance of an Office Space with a Fluid Glass Façade (Munich, Germany, 2013).

118. Pimputkar S., Speck J.S., DenBaars S.P., and Nakamura S.: Prospects for LED lighting. Nat. Photonics 3(4), 180 (2009).

119. Krames M.R., Shchekin O.B., Mueller-Mach R., Mueller G.O., Zhou L., Harbers G., and Craford M.G.: Status and future of high-power light-emitting diodes for solid-state lighting. J. Disp. Technol. 3(2), 160-175 (2007).

120. US Energy Information Administration: Trends in Lighting in Commercial Buildings (US EIA, Washington, 2017).

121. Kumar R. and Rosen M.A.: A critical review of photovoltaic-Thermal solar collectors for air heating. Appl. Energy 88(11), 3603-3614 (2011).

122. Tian Y. and Zhao C-Y.: A review of solar collectors and thermal energy storage in solar thermal applications. Appl. Energy 104, 538-553 (2013).

123. Kennedy C.E.: Review of Mid-to High-Temperature Solar Selective Absorber Materials, Vol. 1617 (National Renewable Energy Laboratory, Golden, CO, USA, 2002).

124. Zambolin E. and Del Col D.: Experimental analysis of thermal performance of flat plate and evacuated tube solar collectors in stationary standard and daily conditions. Sol. Energy 84(8), 1382-1396 (2010).

125. Sanner B., Karytsas C., Mendrinos D., and Rybach L.: Current status of ground source heat pumps and underground thermal energy storage in Europe. Geothermics 32(4), 579-588 (2003).

126. Trillat-Berdal V., Souyri B., and Fraisse G.: Experimental study of a ground-coupled heat pump combined with thermal solar collectors. Energy Build. 38(12), 1477-1484 (2006).

127. Green M.A., Emery K., Hishikawa Y., Warta W., and Dunlop E.D.: Solar cell efficiency tables (Version 45). Prog. Photovoltaics 23(1), 1-9 (2015).

128. Omer S., Wilson R., and Riffat S.: Monitoring results of two examples of building integrated PV (BIPV) systems in the UK. Renew. Energy 28(9), 1387-1399 (2003).

129. Yang H., Zheng G., Lou C., An D., and Burnett J.: Grid-connected building-integrated photovoltaics: A Hong Kong case study. Sol. Energy 76(1), 55-59 (2004).

130. Heinstein P., Ballif C., and Perret-Aebi L-E.: Building integrated photovoltaics (BIPV): Review, potentials, barriers and myths. Green 3(2), 125-156 (2013).

131. Petter Jelle B., Breivik C., and Drolsum Røkenes H.: Building integrated photovoltaic products: A state-of-the-art review and future research opportunities. Sol. Energy Mater. Sol. Cells 100, 69-96 (2012).

132. Shukla A.K., Sudhakar K., and Baredar P.: A comprehensive review on design of building integrated photovoltaic system. Energy Build. 128, 99-110 (2016).

133. Redweik P., Catita C., and Brito M.: Solar energy potential on roofs and facades in an urban landscape. Sol. Energy 97, 332-341 (2013).

134. Tsoutsos T., Farmaki E., and Mandalaki M.: Solar energy for building supply. In Energy Performance of Buildings (2016); pp. 377-398.

135. Lottner V. and Mangold D.: Status of seasonal thermal energy storage in Germany. Proc. Terrastock, 1-8 (University of Stuttgart, Stuttgart, Germany, 2000).

136. Stene J.: Large-Scale Ground-Source Heat Pump Systems in Norway (IEA Annex 29 Workshop, Paris, France, 2008).

137. Hellström G.: Large-Scale Applications of Ground-Source Heat Pumps in Sweden (IEA Heat Pump Annex 29 Workshop, Zurich, 2008).

138. Zalba B., Marín J.M., Cabeza L.F., and Mehling H.: Review on thermal energy storage with phase change: Materials, heat transfer analysis and applications. Appl. Therm. Eng. 23(3), 251-283 (2003).

139. Kaufmann J. and Winnefeld F.: Cement-based chemical energy stores. Patent WO2011147748 A1, 2011.

140. Dicaire D. and Tezel F.H.: Regeneration and efficiency characterization of hybrid adsorbent for thermal energy storage of excess and solar heat. Renew. Energy 36(3), 986-992 (2011).

141. Hongois S., Kuznik F., Stevens P., and Roux J-J.: Development and characterisation of a new $\mathrm{MgSO}_{4}$-zeolite composite for long-term thermal energy storage. Sol. Energy Mater. Sol. Cells 95(7), 1831-1837 (2011).

142. Fumey B., Weber R., Gantenbein P., Daguenet-Frick X., Williamson T., and Dorer V.: Closed sorption heat storage based on aqueous sodium hydroxide. Energy Procedia 48, 337-346 (2014). 
143. Mette B., Kerskes H., and Drück H.: Concepts of long-term thermochemical energy storage for solar thermal applications-Selected examples. Energy Procedia 30, 321-330 (2012).

144. Khudhair A.M. and Farid M.M.: A review on energy conservation in building applications with thermal storage by latent heat using phase change materials. Energy Convers. Manage. 45(2), 263-275 (2004).

145. Zhou D., Zhao C-Y., and Tian Y.: Review on thermal energy storage with phase change materials (PCMs) in building applications. Appl. Energy 92, 593-605 (2012).

146. Jamekhorshid A., Sadrameli S., and Farid M.: A review of microencapsulation methods of phase change materials (PCMs) as a thermal energy storage (TES) medium. Renewable Sustainable Energy Rev. 31, 531-542 (2014).

147. Florides G. and Kalogirou S.: Ground heat exchangers-A review of systems, models and applications. Renew. Energy 32(15), 2461-2478 (2007).

148. Yang H., Cui P., and Fang Z.: Vertical-borehole ground-coupled heat pumps: A review of models and systems. Appl. Energy 87(1), 16-27 (2010).

149. Wang C., Chang Y., Zhang L., Pang M., and Hao Y.: A life-cycle comparison of the energy, environmental and economic impacts of coal versus wood pellets for generating heat in China. Energy 120, 374-384 (2017).

150. Kasurinen S., Jalava P.I., Tapanainen M., Uski O., Happo M.S., Mäki-Paakkanen J., Lamberg H., Koponen H., Nuutinen I., Kortelainen M., Jokiniemi J., and Hirvonen M-R.: Toxicological effects of particulate emissions-A comparison of oil and wood fuels in small- and medium-scale heating systems. Atmos. Environ. 103, 321-330 (2015).

151. Sippula O., Hokkinen J., Puustinen H., Yli-Pirilä P., and Jokiniemi J.: Comparison of particle emissions from small heavy fuel oil and wood-fired boilers. Atmos. Environ. 43(32), 4855-4864 (2009).

152. Zambrana-Vasquez D., Aranda-Usón A., Zabalza-Bribián I., Jañez A., Llera-Sastresa E., Hernandez P., and Arrizabalaga E.: Environmental assessment of domestic solar hot water systems: A case study in residential and hotel buildings. J. Cleaner Prod. 88, 29-42 (2015).

153. Forman C., Muritala I.K., Pardemann R., and Meyer B.: Estimating the global waste heat potential. Renewable Sustainable Energy Rev. 57, 1568-1579 (2016).

154. Eichholz H.D. and Schulz S.: Practical recognized facts from a glass laboratory absorption heatpump for methyl-alcohol working fluid mixtures. Kälte und Klimatechnik 35, 378 (1982).

155. Jernqvist Å., Abrahamsson K., and Aly G.: On the efficiencies of absorption heat transformers. Heat Recovery Syst. CHP 12(4), 323-334 (1992).

156. Ziegler F.: Recent developments and future prospects of sorption heat pump systems. Int. J. Therm. Sci. 38(3), 191-208 (1999).

157. Shelton S.V.: Resedential space conditioning with solid sorption technology. Heat Recovery Syst. CHP 13(4), 353-361 (1993).

158. Meunier F.: Solid sorption heat powered cycles for cooling and heat pumping applications. Appl. Therm. Eng. 18(9), 715-729 (1998).

159. Henninger S., Schmidt F., and Henning H-M.: Water adsorption characteristics of novel materials for heat transformation applications. Appl. Therm. Eng. 30(13), 1692-1702 (2010).

160. Dell R.M. and Rand D.A.J.: Energy storage-A key technology for global energy sustainability. J. Power Sources 100(1), 2-17 (2001).

161. Luthander R., Widén J., Nilsson D., and Palm J.: Photovoltaic selfconsumption in buildings: A review. Appl. Energy 142, 80-94 (2015).

162. Deane J.P., Gallachóir B.Ó., and McKeogh E.: Techno-economic review of existing and new pumped hydro energy storage plant. Renewable Sustainable Energy Rev. 14(4), 1293-1302 (2010).

163. Lund H. and Salgi G.: The role of compressed air energy storage (CAES) in future sustainable energy systems. Energy Convers. Manage. 50(5), 1172-1179 (2009).

164. Cheung B., Carriveau R., and Ting D.S.: Storing energy underwater. Mech. Eng. 134(12), 38 (2012).

165. Divya K. and Østergaard J.: Battery energy storage technology for power systems-An overview. Electr. Power Syst. Res. 79(4), 511-520 (2009).

166. Dufo-López R., Lujano-Rojas J.M., and Bernal-Agustín J.L.: Comparison of different lead-acid battery lifetime prediction models for use in simulation of stand-alone photovoltaic systems. Appl. Energy 115, 242-253 (2014).

167. Nykvist B. and Nilsson M.: Rapidly falling costs of battery packs for electric vehicles. Nat. Clim. Change 5(4), 329-332 (2015).
168. Kim H., Boysen D.A., Newhouse J.M., Spatocco B.L., Chung B., Burke P.J., Bradwell D.J., Jiang K., Tomaszowska A.A., and Wang K.: Liquid metal batteries: Past, present, and future. Chem. Rev. 113(3), 2075-2099 (2012).

169. Kear G., Shah A.A., and Walsh F.C.: Development of the all-vanadium redox flow battery for energy storage: A review of technological, financial and policy aspects. Int. J. Energy Res. 36(11), 1105-1120 (2012).

170. Wang W., Luo Q., Li B., Wei X., Li L., and Yang Z.: Recent progress in redox flow battery research and development. Adv. Funct. Mater. 23(8), 970-986 (2013).

171. Khaligh A. and Li Z.: Battery, ultracapacitor, fuel cell, and hybrid energy storage systems for electric, hybrid electric, fuel cell, and plug-in hybrid electric vehicles: State of the art. IEEE Trans. Veh. Technol. 59(6), 2806-2814 (2010).

172. Dounis A.I. and Caraiscos C.: Advanced control systems engineering for energy and comfort management in a building environment-A review. Renewable Sustainable Energy Rev. 13(6-7), 1246-1261 (2009).

173. Ikeda S. and Ooka R.: Metaheuristic optimization methods for a comprehensive operating schedule of battery, thermal energy storage, and heat source in a building energy system. Appl. Energy 151, 192-205 (2015).

174. Chan M., Estève D., Escriba C., and Campo E.: A review of smart homes-Present state and future challenges. Comput. Meth. Prog. Bio. 91(1), 55-81 (2008).

175. Dorer V. and Weber A.: Energy and $\mathrm{CO}_{2}$ emissions performance assessment of residential micro-cogeneration systems with dynamic whole-building simulation programs. Energy Convers. Manage. 50(3), 648-657 (2009).

176. Široký J., Oldewurtel F., Cigler J., and Prívara S.: Experimental analysis of model predictive control for an energy efficient building heating system. Appl. Energy 88(9), 3079-3087 (2011).

177. Fong K.F., Hanby V.I., and Chow T.T.: HVAC system optimization for energy management by evolutionary programming. Energy Build. 38(3), 220-231 (2006).

178. Attia S., Hamdy M., O’Brien W., and Carlucci S.: Assessing gaps and needs for integrating building performance optimization tools in net zero energy buildings design. Energy Build. 60, 110-124 (2013).

179. Magnier L. and Haghighat F.: Multiobjective optimization of building design using TRNSYS simulations, genetic algorithm, and artificial neural network. Build. Environ. 45(3), 739-746 (2010).

180. Wang J., Zhai Z.J., Jing Y., and Zhang C.: Particle swarm optimization for redundant building cooling heating and power system. Appl. Energy 87(12), 3668-3679 (2010).

181. Oldewurtel F., Parisio A., Jones C.N., Gyalistras D., Gwerder M., Stauch V., Lehmann B., and Morari M.: Use of model predictive control and weather forecasts for energy efficient building climate control. Energy Build. 45, 15-27 (2012).

182. Missaoui R., Joumaa H., Ploix S., and Bacha S.: Managing energy smart homes according to energy prices: Analysis of a building energy management system. Energy Build. 71, 155-167 (2014).

183. Tsui K.M. and Chan S.C.: Demand response optimization for smart home scheduling under real-time pricing. IEEE Trans. Smart Grid 3(4), 1812-1821 (2012).

184. Orehounig K., Evins R., and Dorer V.: Integration of decentralized energy systems in neighbourhoods using the energy hub approach. Appl. Energy 154, 277-289 (2015).

185. Lauster M., Teichmann J., Fuchs M., Streblow R., and Mueller D.: Low order thermal network models for dynamic simulations of buildings on city district scale. Build. Environ. 73, 223-231 (2014).

186. Siano P.: Demand response and smart grids-A survey. Renewable Sustainable Energy Rev. 30, 461-478 (2014).

187. Pacheco R., Ordóñez J., and Martínez G.: Energy efficient design of building: A review. Renewable Sustainable Energy Rev. 16(6), 3559-3573 (2012).

188. Rodriguez-Ubinas E., Montero C., Porteros M., Vega S., Navarro I., Castillo-Cagigal M., Matallanas E., and Gutiérrez A.: Passive design strategies and performance of net energy plus houses. Energy Build. 83, 10-22 (2014).

189. Copiello S.: Economic implications of the energy issue: Evidence for a positive non-linear relation between embodied energy and construction cost. Energy Build. 123, 59-70 (2016). 
190. Greening L.A., Greene D.L., and Difiglio C.: Energy efficiency and consumption-The rebound effect-A survey. Energy Policy 28(6-7), 389-401 (2000).

191. Sorrell S., Dimitropoulos J., and Sommerville M.: Empirical estimates of the direct rebound effect: A review. Energy Policy 37(4), 1356-1371 (2009).

192. Böninger M.: Wie viel Wohnraum braucht der Mensch?-Stadt Zürich (2013). Available at: https://www.stadt-zuerich.ch/prd/de/index/ statistik/publikationen-angebote/publikationen/webartikel/2013-03-28_ Wie-viel-Wohnraum-braucht-der-Mensch.html (accessed December 5, 2016).

193. Wie private Haushalte die Umwelt nutzen-Höherer Energieverbrauch trotz Effizienzsteigerungen (Umwelt Bundesamt, 2006). Available at: https:// www.destatis.de/DE/PresseService/Presse/Pressekonferenzen/2006/ UGR/UBA_Hintergrundpapier.pdf?__blob=publicationFile (accessed December 5, 2016).

194. Galvin R.: Making the "rebound effect" more useful for performance evaluation of thermal retrofits of existing homes: Defining the "energy savings deficit" and the "energy performance gap". Energy Build. 69, 515-524 (2014).

195. Kerr R. and Toy D.: Final Report: Occupied Home Evaluation Results (Building Industry Research Alliance (BIRA), Stockton, CA, 2007). Available at: https://www.consol.ws/services/consulting/files/reports/ Final_Report_16D2_OccupiedHomeEvaluationResults.pdf (accessed December 5, 2016).
196. Janda K.B.: Buildings don't use energy: People do. Archit. Sci. Rev. 54(1), 15-22 (2011).

197. Stevenson F. and Leaman A.: Evaluating housing performance in relation to human behaviour: New challenges. Build. Res. Inf. 38(5), 437-441 (2010).

198. Energieplanungsbericht 2013 (AWEL, Abteilung Energie, Zürich, 2013). Available at: https://www.zh.ch/internet/de/aktuell/news/ medienmitteilungen/2014/energieplanungsbericht_zeigt_erfolge_ und_herausforderungen.html (accessed October 18, 2017).

199. Ma Z., Cooper P., Daly D., and Ledo L.: Existing building retrofits: Methodology and state-of-the-art. Energy Build. 55, 889-902 (2012).

200. Kumbaroğlu G. and Madlener R.: Evaluation of economically optimal retrofit investment options for energy savings in buildings. Energy Build. 49, 327-334 (2012).

201. Asadi E., da Silva M.G., Antunes C.H., Dias L., and Glicksman L.: Multi-objective optimization for building retrofit: A model using genetic algorithm and artificial neural network and an application. Energy Build. 81, 444-456 (2014).

202. Girod B., Lang T., and Nägele F.: Energieeffizienz in Gebäuden: Herausforderungen und Chancen für Energieversorger und Technologiehersteller (2014). Available at: http://www.sustec.ethz.ch/ content/dam/ethz/special-interest/mtec/sustainability-and-technology/ PDFs/SER_Final_report.pdf (accessed December 5, 2016).

203. Achtnicht M. and Madlener R.: Factors influencing German house owners' preferences on energy retrofits. Energy Policy 68, 254-263 (2014). 